\title{
Review
}

\section{PI3K and Akt as molecular targets for cancer therapy: current clinical outcomes}

\author{
Ipsita PAL, Mahitosh MANDAL* \\ School of Medical Science and Technology, Indian Institute of Technology Kharagpur, Kharagpur 721302, India
}

\begin{abstract}
The PI3K-Akt pathway is a vital regulator of cell proliferation and survival. Alterations in the PIK3CA gene that lead to enhanced PI3K kinase activity have been reported in many human cancer types, including cancers of the colon, breast, brain, liver, stomach and lung. Deregulation of PI3K causes aberrant Akt activity. Therefore targeting this pathway could have implications for cancer treatment. The first generation PI3K-Akt inhibitors were proven to be highly effective with a low $\mathrm{IC}_{50}$, but later, they were shown to have toxic side effects and poor pharmacological properties and selectivity. Thus, these inhibitors were only effective in preclinical models. However, derivatives of these first generation inhibitors are much more selective and are quite effective in targeting the PI3K-Akt pathway, either alone or in combination. These second-generation inhibitors are essentially a specific chemical moiety that helps to form a strong hydrogen bond interaction with the PI3K/Akt molecule. The goal of this review is to delineate the current efforts that have been undertaken to inhibit the various components of the PI3K and Akt pathway in different types of cancer both in vitro and in vivo. Our focus here is on these novel therapies and their inhibitory effects that depend upon their chemical nature, as well as their development towards clinical trials.
\end{abstract}

Keywords: anticancer drug; kinase inhibitors; PI3K; Akt; clinical trials

Acta Pharmacologica Sinica (2012) 33: 1441-1458; doi: 10.1038/aps.2012.72; published online 17 Sep 2012

\section{Introduction}

The phosphoinositol-3- kinase (PI3K) pathway was discovered in human cancers over 20 years ago as an enzymatic activity associated with a viral oncoprotein. This pathway has received much attention in the study of human cancer because it is important for the cell cycle, proliferation, growth, survival, protein synthesis and glucose metabolism ${ }^{[1]}$. PI3K pathway deregulation is the driver in approximately $30 \%$ of all cancers. This deregulation occurs via various genetic and epigenetic mechanisms and leads to a wide range of tumor types.

PI3K is a heterodimer with p85 regulatory and p110 catalytic subunits. The class IA PI3K consists of a p85a regulatory subunit and its truncated splice variants p50a and p55a, as well as p85 $\beta$ and $p 55 \gamma$ and one of several p110 catalytic subunits $(\alpha, \beta \text {, or } \delta)^{[2,3]}$. The regulatory subunits $p 85 a, p 50 a$, and p55a are encoded by the PIK3R1 gene. Evidence suggests that p85a is the most abundantly expressed regulatory isoform of PI3K, and p55a and p50a are two minor alternative splicing isoforms ${ }^{[4,5]}$. The p110 subunit is encoded by the PIK3CA gene and has three isoforms: $\alpha, \beta$, and $\delta$. The p110a isoform is the

\footnotetext{
* To whom correspondence should be addressed.

E-mail mahitosh@smst.iitkgp.ernet.in

Received 2012-03-14 Accepted 2012-05-11
}

most common and important subunit in PI3K and the components of p110 include an N-terminal p85-binding domain (p85BD), a RAS binding domain (RBD), a protein-kinase-C homology-2 (C2) domain, a helical domain, and a C-terminal kinase domain. Class IB PI3K comprises p101 regulatory and $\mathrm{p} 110 \gamma$ catalytic subunits, which feature similar activity ${ }^{[6]}$. These two types of enzymes catalyze the phosphorylation of lipid substrate phosphatidylinositols such as $\mathrm{PI}(4) \mathrm{P}$ and $\mathrm{PI}(4,5)$ $\mathrm{P} 2$ at their D3 position and the resulting product is PI-3,4,5-P3, which activates downstream signaling pathways through the phosphorylation of several kinases. These kinases include Akt and 3-phosphoinositide-dependent kinase (PDK) and appear to be involved in the regulation of cellular responses varying with the cell types and stimuli studied ${ }^{[7]}$.

\section{The role of receptors in PI3K deregulation}

The class I PI3K is activated by receptor tyrosine kinases (RTK). RTK activation results in the association of PI3K with the receptor through one or two SH2 domains in the adaptor unit binding to phosphotyrosine consensus motifs. Previously published data suggest that allosteric activation of the catalytic subunit of PI3K in this manner leads to PI-3,4,5-P3 production within a few seconds. The effect of polyphosphoinositide on cells is mediated through specific binding to at least two dis- 
tinct protein-lipid binding domains, such as Fab-1, YGL023, Vps27, and EEA1 domain (FYVE) and pleckstrin homology $(\mathrm{PH})$ domains. Proteins containing the latter domain are critical mediators for PI3K class IA-induced signaling. The protein serine/threonine kinase 30-phosphoinositidedependent kinase1 (PDK1) and Akt/PKB are both critical for the transforming effects of deregulated PI3K activity. Liganddependent activation of protein tyrosine kinase receptors and receptors coupled with either G-proteins or integrins results in PI3K activation. Such activation may also occur independently of the receptor, as is the case in cells expressing constitutively active Ras. PI3K activation can also occur in the presence of some selected receptor families (eg, EGF and FGF) in cases where they are missing the consensus sequence of the p85 regulatory subunit, necessary for PI3K activation ${ }^{[8]}$.

\section{ErbB receptor family and their role in PI3K/Akt activation}

Among the surface receptor tyrosine kinases, the epidermal growth factor receptor (ErbB) family can also cause the deregulation of the PI3K pathway. The ErbB receptor family consists of the following four members: ErbB1/Her1, ErbB2/ Neu/Her2, ErbB3/Her3, and ErbB4/Her4. ErbB ligand (EGF related peptide growth factor) binding leads to receptor dimerization followed by the activation of an intrinsic tyrosine residue that provides docking sites for PI3K. One unique characteristic of the ErbB receptor family is the ability to form both homodimers and heterodimers. Heterodimer formation leads to signal amplification as well as signal diversification. Interestingly, ErbB2 has the efficiency to form dimers independently of ligand availability, which attributes an important role in tumorigenesis in a large number of breast and ovarian cancers. The synergistic ability of ErbB2 to form dimers with most commonly ErbB3, as well as other ErbB receptors, has clear impact on abnormal cell proliferation as well as tumor progression. It has been shown that ErbB2-ErbB3 dimers are activators of the PI3K-Akt pathway ${ }^{[9]}$. Studies in breast cancer cells, primary breast tumors, and transgenic mice all indicate that ErbB2, when overexpressed, is constitutively associated with ErbB3 ${ }^{[10]}$. ErbB3 possesses seven phosphorylale tyrosine residues that act as binding sites for the $\mathrm{SH} 2$ domains of the p85 regulatory subunit of PI3K. Tumor cells overexpressing ErbB2 shows constitutive Akt activity ${ }^{[11]}$.

\section{Insulin receptors and their role in $\mathrm{PI} 3 \mathrm{~K} / \mathrm{Akt}$ activation}

The insulin receptor (IR) and the type 1 insulin-like growth factor receptor (IGFR) evolved from a single ancestral receptor protein and have $70 \%$ homology with respect to protein structure. Both proteins are receptor tyrosine kinase that consist of two half-receptors, each comprising one extracellular alphasubunit and one transmembrane beta-subunit that possess tyrosine kinase activity ${ }^{[12]}$.

Current data suggest that insulin resistance has a great impact on cancer progression. Insulin resistance that develops in cancer patients leads to increased levels of circulating insulin combined with IR overexpression. This phenomenon results in abnormal stimulation of the nonmetabolic effects of IR, such as cell survival, proliferation and migration. IR is activated by insulin, which is generally secreted from the pancreas.

IR has two isoforms: IR-A and IR-B. Although IR-B has a greater specificity and affinity for insulin, it plays a less important role in cancer progression than IR-A. Current evidence suggests that IR-A is overexpressed in many malignancies and signaling through IR-A results in more mitogenic effects than signaling through IR-B, which activates the metabolic signaling pathway. Recently, it was found that IR can activate metabolic pathways independently of IGF binding. The main activation mechanism of IR is via the RAS/Raf/MEK/ MAPK pathway. The PI3K pathway is the second most common option for IR activation, which occurs via the activation of Akt and mTOR/p70S6K. After insulin binding to IR and subsequent activation of IRS1, activated PI3K catalyzes the production of PI-3,4,5-P3, which results in the phosphorylation of PDK1 and several downstream enzymes, including Akt and PKC. Based on cellular context, Akt can activate or inhibit several proteins involved in glucose and lipid metabolism (ie, GLUT4, PDE3B, Foxa2, GSK3, and AMPK), as well as in cell growth, division, and survival. IR-A has a greater affinity towards the IGFs, especially for IGF2, which is a primary cause of tumorigenesis in many cancer discussed below ${ }^{[13]}$.

As discussed above, increased levels of insulin in the portal circulatory system cause an increase in the expression of the growth receptor and an increase in IGF-I production.

Earlier evidence showed that higher level of IGF-I has been observed in colorectal, pre-menopausal breast cancer, and prostate cancer. In vivo studies using p53-deficient mice and LID mice with colon adenocarcinomas demonstrated that IGF-I deficiency reduces tumor growth. In addition to the growth-promoting effects of insulin and IGF-I, IGF-II overexpression has also been observed to play a role in tumor development. IGF-II is produced in the liver and many other tissues in adult humans. In contrast, in rats IGF-II expression decreases in postnatal life and is only expressed to a significant degree in the adult rat brain. In normal conditions, IGF-II expression is controlled by the paternal chromosome under the control of the differentially methylated region (DMR) associated with the H19 gene located upstream on chromosome 11. A loss of imprinting resulting from the methylation of the DMR on the maternal allele leads to overexpression of IGF-II, which has been observed in many tumor types ${ }^{[14]}$.

Insulin-like growth factor binding proteins (IGFBPs) play an important role in the stabilization of IGF-I and -II. Among the 6 IGFBP proteins, named IGFBP-1 to IGFBP-6, IGFBP-3 is the most predominant. These binding of proteins increase the circulating half-lives of IGF-I and IGF-II and protect them from further degradation. The main disadvantage of the IGFBPs is that although they increase the stability of IGF, they in turn reduce the availability of IGF for receptor binding ${ }^{[14]}$.

IGFR consists of two isoforms: IGF-1R and IGF-2R. These two isoforms, along with the insulin receptors, form the hybrid receptors IGF-1R/IR-A and IGF-1R/IR-B. All of the IGF receptors have significant homology, thus resulting in 
structural similarity and the possibility of signaling crosstalk. IGF-1R is a tetrameric receptor consisting of two a-subunits and two transmembrane $\beta$-subunits that are linked by disulfide bonds. The a-subunits are extracellular and bind IGF. Each transmembrane $\beta$-subunit contains an intracellular tyrosine kinase domain. Binding of IGF-I or IGF-II ligand to IGF-1R leads to the phosphorylation of three key tyrosine residues in the kinase domain, leading to the phosphorylation of downstream substrates. In addition, the phosphorylation of additional tyrosine residues in other areas of the $\beta$-subunit provide "docking sites" that allow for the recruitment of adaptor proteins. Insulin receptor substrate family members are some of the many adaptor proteins that are known to have an important role in IGF-1R signaling ${ }^{[15]}$.

Ligand binding to IGF-1R causes its autophosphorylation and the tyrosine phosphorylation of IGF-IR substrates, especially the IR substrate 1 (IRS-1) and the Src and collagenhomology (SHC) protein. Tyrosine-phosphorylated IRS-1 and SHC bind different effector proteins (enzymes and/or adapters), inducing multiple signaling cascades, including several interconnecting pathways that control cell survival and proliferation. The critical survival pathway is activated by IGF-I stems from IRS-1. IRS-1 recruits and stimulates PI3K due to the presence of the same homology domain, which then transmits the signal to $\mathrm{Akt}^{[12,15,16]}$.

\section{PDGF receptors and their role in $\mathrm{PI}$ KK/Akt activation}

The PDGF family of signaling molecules regulates the growth and motility of connective tissue cells. PDGF is a dimer that consists of disulphide bonded homologous A and B-polypeptide chains. These A and B-polypeptides arrange themselves to form homodimers (PDGF-AA/BB) and heterodimers (PDGF-AB). PDGF isoforms act upon their target cells by binding to two structurally related protein tyrosine kinase receptors. PDGF receptors have two isoforms, $a$ and $\beta$. The a-receptor binds both the A- and B-chains of PDGF, whereas the $\beta$-receptor binds only the $\mathrm{B}$-chain. Due to these properties, the PDGF-AA and PDGF-BB homodimers typically tend to bind with the PDGF-a and $-\beta \beta$ receptors, respectively. However, PDGF-AB binds only the $\beta$ receptors. The $\alpha-$ and $\beta$-receptors for PDGF each contain five extracellular immunoglobulin domains and one intracellular tyrosine kinase domain with a characteristic inserted sequence ${ }^{[17]}$.

The main event of PDGF activation is receptor dimerization. The close interaction between the kinase domains of the receptors causes phosphorylation in trans between the receptors, which is called autophosphorylation. The main purpose of this autophosphorylation is to regulate the catalytic activity of the kinase and provide a docking site for further downstream target molecule regulation. It has been observed that the tyrosine residues play the major role in the autophosphorylation process. In the case of the $\beta$-receptor, the phosphorylation site is Tyr857, which is located inside the kinase domain. This tyrosine is conserved in the a-receptor (Tyr849) and in almost all other tyrosine kinase receptors. Mutational analysis studies demonstrated that replacing the tyrosine with phe- nylalanine caused lower kinase activity. The involvement of various domains helps to a great extent in an intracellular system. These include the Src homology 2 (SH2) domains and the phosphotyrosine binding (PTB) domains that recognize phosphorylated tyrosine residues in specific environments, the $\mathrm{SH} 3$ domains that recognize proline-rich regions, the pleckstrin homology $(\mathrm{PH})$ domains that recognize membrane phospholipids and the PDZ domains that recognize a C-terminal valine residue $^{[18]}$. Current data suggest that more than 10 different SH2-domain-containing molecules tend to bind to different autophosphorylation sites in the PDGF $\alpha$ - and $\beta$-receptors. There are two types of molecules that bind to the $\mathrm{SH} 2$ domains of PDGF receptors: enzymes that have catalytic activity and adaptor molecules that help to bind other molecules. Phosphatidylinositol 3'-kinase is one such molecule that is activated by PDGF ${ }^{[19]}$.

PI3K activates PDGF by interacting with the SH2 domain of the p85 subunits. Two tyrosines with a methionine at the +3 position are present in the PDGF $\beta$-receptor (ie, Tyr740 and Tyr751) in the autophosphorylation sites, which helps to bind PI3K. Both of these tyrosines are conserved in the a-receptor, where they are also important for the binding of PI3K. The p85 subunit of PI3K has been shown to be phosphorylated at Tyr508 after binding to the PDGF $\beta$-receptor, but it is not clear if this has any functional relevance. However, the binding of p85 to a phosphorylated region of a protein has been shown to lead to a conformational change and increased enzymatic activity of the associated catalytic subunit ${ }^{[19]}$.

\section{VEGF and its role in PI3K/Akt activation}

Vascular endothelial growth factor (VEGF) is an endothelial cell (EC)-specific mitogen and chemotactic agent that is involved in wound repair, angiogenesis of ischemic tissue, tumor growth, microvascular permeability, vascular protection, and hemostasis. VEGF predominantly known as VEGF-A, belongs to the VEGF-PDGF supergene family. The other family members of the VEGF family include VEGF-B, VEGF-C, VEGF-D, and VEGF-E, which all show varying degrees of homology with VEGF-A. Alternative splicing of VEGF results in four isoforms containing 121, 165, 189, or 206 amino acids. The dominant form of VEGF 165 is a $45 \mathrm{kDa}$ homodimeric glycoprotein that exists in a partly matrix and partly membrane bound form. The VEGF isoforms 189 and 206 are basic and mainly stay in the extracellular matrix. The VEGF 121 isoform is acidic and is secreted ${ }^{[20]}$.

The VEGF family of proteins binds to three receptor-type tyrosine kinases: Flt-1 (VEGF receptor-1), KDR/Flk-1 (VEGF receptor-2), and VEGFR-3. VEGFR-1 and -2 are normally expressed in vascular ECs, whereas VEGFR-3 is expressed in the lymphatic endothelium. Of the VEGF receptors, KDR/ Flk-1 is believed to play the most important role in mediating EC proliferation, migration, and permeability ${ }^{[21]}$. VEGFR-1 is able to bind VEGF, VEGF-B, and placental growth factor. VEGFR-2 is activated primarily by VEGF, but proteolytically cleaved forms of VEGF-C and VEGF-D may also activate this receptor. VEGFR-3 is activated only by VEGF-C and 
VEGF-D ${ }^{[22]}$.

From gene targeting studies in mice, it has been proven that VEGF and VEGFR have remarkable effects on the development of the vascular system. Vegfr2-/- mice die between embryonic day 8.5 and 9.5 due to defects in the development of hematopoietic and endothelial cells, resulting in impaired vasculogenesis $^{[23]}$.

The mechanism of VEGF activation involves receptor dimerization followed by autophosphorylation on several tyrosine residues and initiation of intracellular signaling pathways. These pathways are mediated by several effectors, which consist of docking sites composed of the phosphorylated tyrosine residues of the activated receptors. These interactions are mediated by Src homology 2 domains, phosphotyrosine-binding domains and other domains of the signaling proteins. Recent data demonstrate that VEGFR-2 is a major component of the VEGF mediated response in endothelial cells and it plays a critical role in signal transduction in both physiologic and pathologic angiogenesis.

Tyrosine 1175 in human VEGFR-2 has been identified as a major autophosphorylation site following VEGF binding. It serves as a docking site for phospholipase C- $\gamma^{[24]}$, which indirectly mediates the activation of the mitogen activated protein kinase pathway that regulates cell proliferation. After VEGF stimulation, VEGFR-2 is phosphorylated at Tyr1175 and Src associates with the receptor, which results in the binding of the SH2 domain of Shb to the phosphorylated Tyr1175 in the C-terminal tail of VEGFR-2. Src phosphorylates Shb, which allows the subsequent activation of $\mathrm{PI} 3 \mathrm{~K}^{[25]}$. Previous studies demonstrated that Akt is required for the VEGF-mediated survival signal $^{[26]}$. Thus, VEGF-mediated signaling acts through the PI3K-Akt pathway ${ }^{[27]}$.

\section{The role of G-protein coupled receptors in the activation of PI3K} class IA and IB

In previous sections of this review, it was discussed that the class I PI3K is activated by RTKs. However, recent data indicate that most class I PI3K subunits might be activated by G protein-coupled receptors (GPCRs), either directly through $\mathrm{G} \beta \gamma$ protein subunits (in the case of $\mathrm{p} 110 \beta$ and $\mathrm{p} 110 \gamma$ ) or indirectly, for example through Ras. The class IB regulatory subunits (p84 and p101) do not have SH2 domains and they link

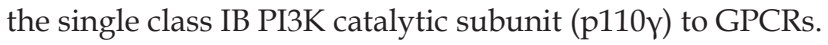

GPCRs are a superfamily of seven transmembrane spanning proteins that consist of $\mathrm{Ga}$ and $\mathrm{G} \beta \gamma$ subunits. The activation of GPCRs involves the coupling of agonist-activated GPCRs to a wide variety of effector systems via their interaction with heterotrimeric guanine nucleotide binding proteins ( $\mathrm{G}$ proteins). The binding of an agonist to a GPCR selects for a receptor conformation state that promotes the exchange of GDP for GTP on the G protein a-subunit, which is presumed to allow the dissociation of the G protein Ga- and G $\beta \gamma$-subunits. Subsequently, the activated Ga- and G $\beta \gamma$-subunits can either positively or negatively regulate the activities of effector enzymes and ion channels ${ }^{[28]}$.

Earlier it was discussed that class IB consists of p101 regula- tory and p110y catalytic subunits. Due to the absence of the p85 subunit, the p110y catalytic subunit of the class IB PI3K does not form a complex with p85 but is instead activated directly by $\mathrm{G} \beta \gamma$ ( $\beta$ Y subunits of GTP-binding protein). The tightly associated regulatory p101 subunit is not essential for $\mathrm{G} \beta \gamma$-induced activation of $\mathrm{p} 110 \gamma$ but rather plays a role in recruiting $\mathrm{p} 110 \mathrm{\gamma}$ to the plasma membrane and determining substrate specificity. The non-catalytic p101 subunit is also known to determine the substrate specificity of $\mathrm{p} 110 \gamma$. The molecular mechanisms of the G $\beta \gamma$-induced activation of $\mathrm{p} 110 \gamma$ have been shown to involve the direct interaction of G $\beta \gamma$ with both the $\mathrm{NH}_{2}-$ and $\mathrm{COOH}$-terminal of $\mathrm{p} 110 \gamma^{[29]}$. These data suggest that the major isoform of PI3K that is transmitting the signal from GPCRs is $\mathrm{p} 110 \gamma$. On the other hand, data suggest that GPCRs cause the activation of class IA PI3K in many cell lines, including hematopoietic cells. One of the possible mechanisms for this activation is that $\mathrm{p} 110 \beta$, one of the catalytic subunits of class IA PI3Ks, is activated by G $\beta$ Y in cell-free systems. Other members of the class IA PI3Ks, p110a and p1106, show no sensitivity to G $\beta \gamma$. However, the structural basis for the $G \beta \gamma$ sensitivity of $p 110 \beta$ has not been examined ${ }^{[30]}$.

\section{PI3K deregulation by mutational approach}

Deregulation of PI3K is most commonly due to the amplification of the PIK3CA gene. It has also been suggested that mutations in the PIK3R1 gene, which encodes the p85 subunit, lead to the activation of $\mathrm{p} 110^{[29]}$. Activating somatic mutations in the p85a regulatory subunit of PI3K (PIK3R1) are prevalent in primary ovarian, colon, and breast cancer ${ }^{[31]}$. Interestingly, more than $80 \%$ of the mutations in the PIK3CA cluster have been found in two small conserved regions within the helical and kinase domains ${ }^{[32]}$. These include three hot spots that result in single amino acid substitutions. The first two hotspots are in exon eight and lead to E545K and E542K mutations in the helical domain. The third hotspot is located in exon twenty and produces a H1047R mutation in the kinase domain by replacing arginine. These first two mutations act cooperatively and relieve the inhibitory effect of p 85 on p110a, and the third mutation allows for easier access to p110a in the membrane. Therefore, these mutations lead to increased kinase activity. The non-random distribution of these changes in highly conserved regions results in a series of cellular responses, including increased enzymatic function, enhanced downstream signaling elements, including Akt, and enhanced oncogenic transformation ${ }^{[33,34]}$.

Although PIK3CA mutations and ErbB overexpression are critical drivers of tumor development, mutations in the PTEN lipid phosphatase are also found to be major causes for PI3K activation in human cancer. The main substrate of PTEN is PIP3. PTEN dephosphorylates PIP3 at the D3 position and acts as a negative regulator of PI3K signaling. In addition, PTEN also acts as tumor suppressor gene. Mutation of PTEN leads to the formation of sporadic cancers, including glioblastoma, endometrial carcinoma, melanoma and bladder, lung and lymphatic cancer ${ }^{[35]}$. 
The mechanisms of Akt activation, deregulation and oncogenesis

Akt is one of the downstream targets of PI3K. It is a serine/ threonine kinase that is activated due to the formation of PIP3 by PI3K. PIP3 binds the PH domains of Akt and aids in the recruitment of Akt to the plasma membrane, which alters the conformation of Akt to allow for subsequent phosphorylation by PDK $1^{[36]}$. 3-Phosphoinositides help to increase the phosphorylation of this residue to achieve Akt activation. Akt is activated through the phosphorylation of Thr308, but phosphorylation of the Ser 473 residue located at the hydrophobic C-terminal region is also required for full activation of the kinase ${ }^{[8]}$. Phosphorylation of Thr308 helps to increase the activation of Akt approximately 100-fold. However, full activation requires the phosphorylation of the Ser473 residue. A different hypothesis regarding Ser 473 activation has been proposed for decades. However, recent data have shown that the kinases that aid in this activation are members of the PIKK (PI3 kinase-related kinase) superfamily (mammalian target of rapamycin complex 2 (mTORC2) and DNA-PK) ${ }^{[37]}$.

mTORC2 is composed of mTOR, rictor, mSIN1, and mLST8. The most important function of mTORC2 is the phosphorylation of Akt on Ser473. Studies suggest that targeting TSC2 deficient cells with a myristoylation sequence (myr-Akt) that is independent of the PI3K pathway and $\operatorname{Sin} 1^{-/-}$MEFs, which completely lack mTORC2 activity, show a higher level of Ser473 phosphorylation. From this study, it can be concluded that recruiting Akt to the plasma membrane through either increased PI3K activity or membrane-targeting sequences is sufficient to stimulate phosphorylation at Ser473 under conditions of low or even no mTORC2 activity ${ }^{[38]}$.

The contribution of Ser473 phosphorylation in the regulation of Thr308 phosphorylation, Akt activity, and phosphorylation of downstream substrates is not yet fully understood. Initial studies using alanine mutants shows that Akt Thr308 and Ser473 can be phosphorylated independent of each other. Recent evidences confirm that mice deficient in the mTORC2 components rictor, mSIN1 or mLST8 have selective inhibition of Ser473 phosphorylation, leaving the majority of Thr308 phosphorylation intact. In contrast, RNA interference of rictor, which disrupts the mTORC2 complex, and small molecule inhibitors of mTOR decrease both Ser473 and Thr308 phosphorylation, suggesting that Ser473 phosphorylation can facilitate Thr308 phosphorylation ${ }^{[39]}$.

Akt activity is controlled by several molecules that help to dephosphorylate Akt. Among these negative regulators, PP2A (protein phosphatase 2A) regulates Akt activity by inducing Akt Thr308 dephosphorylation. The PH domain leucine-rich repeat protein phosphatase (PHLPP) suppresses Akt activity by dephosphorylating Akt at Ser473. FKBP51 (FK506 binding protein 51) helps maintain the interaction between PHLPP and Akt, serves as a scaffold for Akt and PHLPP and negatively regulates Akt phosphorylation at Ser473. Akt regulates itself like an autocrine system because its activity is controlled by phosphorylation and dephosphorylation cycles within the Akt molecules. Akt phosphorylation and activation is also regulated by promyelocytic leukemia protein (PML) tumor suppressor. PML forms a complex with PP2A and Akt and facilitates PP2A-mediated Akt dephosphorylation at Thr308. PML cooperates with the PTEN tumor suppressor to restrict prostate cancer development in an animal model of the disease $^{[40]}$.

\section{Akt activation due to cellular stress}

Akt activation often occurs due to the cellular stress response, which is independent of the PI3K pathway. Interestingly, each Akt subtype responds to different stimuli because the response of Akt to cellular stress differs slightly among the family. Stimulation of cells with $\mathrm{H}_{2} \mathrm{O}_{2}, \mathrm{CdCl}_{2}$, and $\mathrm{NaAsO}_{2}$ activates different Akt subtypes that show distinct responses. This cellular stress-mediated Akt activation occurs due to the association of Akt with Hsp27. By binding Akt, Hsp27 helps to alter the conformation of Akt, which is required for phosphorylation $^{[41]}$. Recent data have shown that oxidative stress induced Akt activation, which leads to apoptosis though the increased expression of FOXO3a. This increased FOXO3a expression in turn increases the expression of its transcriptional targets Bim and $\mathrm{p} 27 \mathrm{kip} 1^{[42]}$.

Deregulation of the Akt pathway occurs due to the genetic amplification of the Akt gene. The three isoforms of Akt that have been identified are Akt1, Akt2, and Akt3. These three isoforms are the protein products of the Akt1, Akt2, and $A k t 3$ genes, respectively. It has been found that ovarian, breast, pancreatic, and gastric cancer can be caused by Akt gene amplification ${ }^{[43,44]}$. Akt activates a cascade of reactions through the phosphorylation of several molecular targets. Akt activates mTORC-1, a complex also modulated by ERK, which leads to the stimulation of protein synthesis and cell growth by regulating both the ribosomal p70S6 kinase (S6K) and the eukaryotic translation initiation factor $4 \mathrm{E}(\mathrm{eIF} 4 \mathrm{E})^{[45]}$. Akt regulates cell cycle progression and events associated with them by modulating cell cycle inhibitors, such as p21, p27kip1, and GSK3, and cell cycle stimulators, such as c-myc and cyclin D1, by phosphorylation ${ }^{[36]}$. Akt also regulates apoptosis by inhibiting the translocation of the forkhead family of proteins from the cytoplasm to the nucleus. Inhibiting this translocation blocks transcription of the death genes FASL and $\operatorname{BIM}^{[46,47]}$, increases the transcription of survival genes by NF- $\mathrm{KB}$ and CREB transcription factor activation ${ }^{[48,49]}$, phosphorylates and inactivates the proapoptotic protein $\mathrm{BAD}^{[50,51]}$, and maintains mitochondrial integrity by activating hexokinase (Figure 1). Akt regulates many cellular processes, including differentiation, proliferation and transformation by phosphorylating GSK- $3^{[52,53]}$. Through the upregulation of the transcription repressor Snail, Akt modulates the induction of the epithelialmesenchymal transition and tumor cell invasion. Akt/ mTORC1 induces the expression of HIF-1 and VEGF, which are key elements involved in angiogenesis. Feedback inhibition mechanisms have also been identified in this complex pathway. One of the most notable examples that has clinical relevance is the ability of S6K to phosphorylate and inhibit IRS-1, an upstream member of the PI3K/Akt pathway ${ }^{[54]}$. 


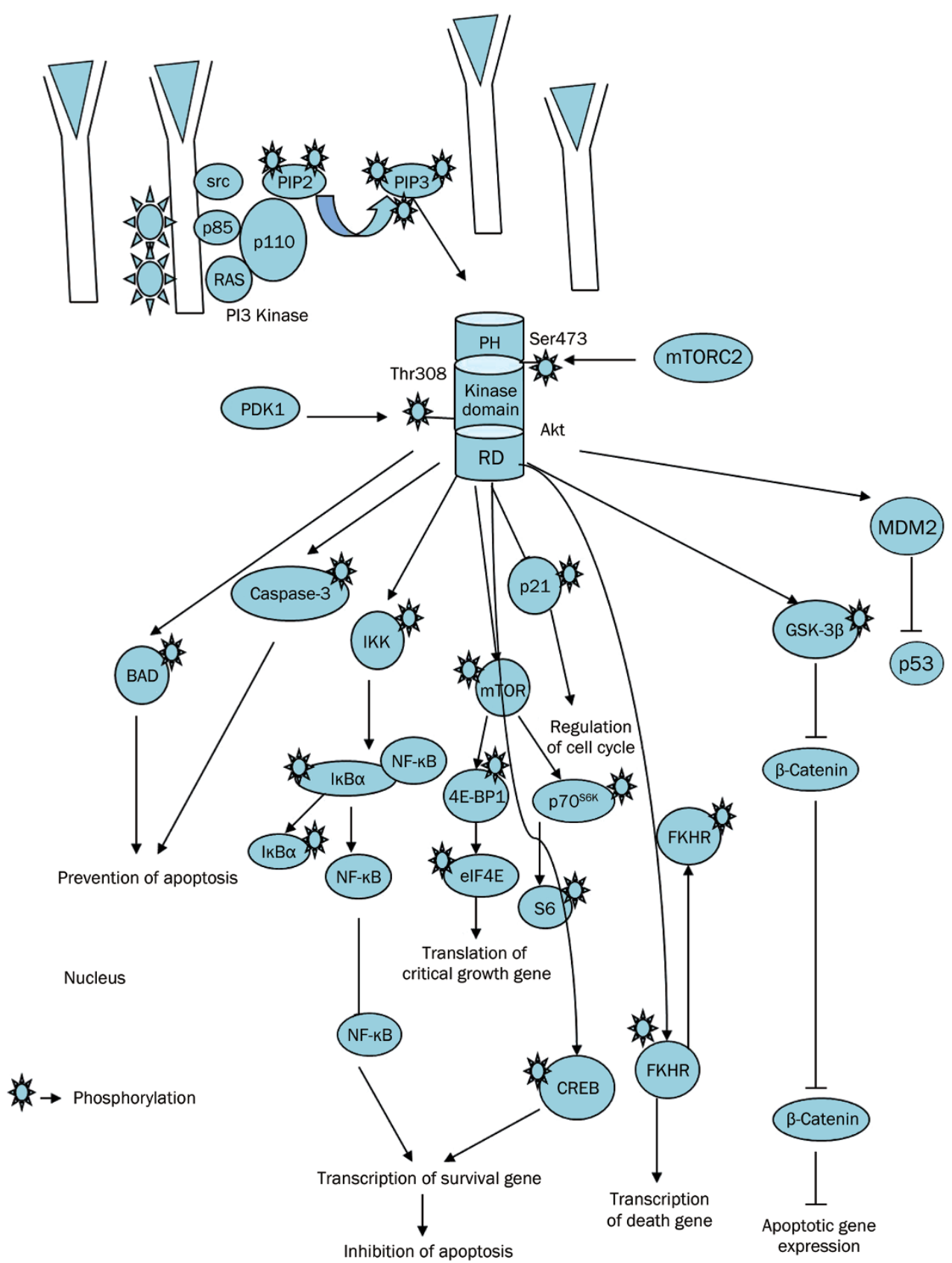

Figure 1. Schematic representation of PI3K-AKT pathway and associated cellular activities. PDK2 is shown as mTORC2. Continuous lines represent direct AKT phosphorylation, leading to activation (arrow end) or inhibition (blunt end). PI3K kinase consists of p110 catalytic and p85 regulatory subunits. PI3K is activated by receptor tyrosine kinases. Once, activated PI3K converts phosphatidylinositol 3,4-bisphosphate (PIP2) to phosphatidylinositol 3,4,5-trisphosphate (PIP3). PIP3 helps to recruit PH domain binding protein like Akt to cell membrane and thus activates Akt. The recruitment of Akt to cell membrane leads to the conformational changes in Akt and helps PDK1 for phosphorylation at Thr308 residue. The complete activation of Akt requires phosphorylation of AKT at the hydrophobic C-terminal domain Ser473 residue. This phosphorylated AKT regulates apoptosis and various cellular activities by phosphorylating various downstream substrates.

\section{PI3K inhibitors}

The PI3K inhibitor LY294002 and wortmannin are first generation pan-PI3K inhibitors that act as ATP competitive manner. Wortmannin inhibits PI3K activity by binding covalently to a conserved lysine residue in the ATP binding site of the enzyme ${ }^{[55]}$. LY294002 is a flavonoid derivative and a revers- ible, ATP-competitive inhibitor that has an $\mathrm{IC}_{50}$ for recombinant PI3K in the low micromolar range ${ }^{[56]}$. Wortmannin and LY294002 both have anti-proliferative and apoptotic effects in vitro and in vivo ${ }^{[56-58]}$. Wortmannin and LY294002 are effective inhibitors of PI3K, but the use of these two compounds is limited to the preclinical level due to their instability in aque- 
ous solutions, toxic side effects, poor pharmaceutical properties, and lack of selectivity for the oncogenic class I PI3K isoforms ${ }^{[59]}$ (Table 1).

To overcome these pharmacological problems, including poor solubility and lack of selectivity, LY294002 was recently conjugated with an RGD-containing peptide. This conjugation of LY294002 to RGDs results in increased solubility and binding to specific integrins (primarily av $\beta 3$ and a5 $\beta 1$ ) in the tumor compartment, which helps to target stromal endothelial and tumor cells, depending upon effect of LY294002 on the microenvironment. The anticancer effects of SF1126 (Figure 2) have been observed in a wide variety of in vitro and in vivo systems, including renal cell carcinoma, glioblastoma, neuroblastoma, and rhabdomyosarcoma, as well as in breast and prostate cancer xenografts ${ }^{[60]}$. Recent studies have found that SF1126, in combination with other chemotherapeutic agents, has a more profound anticancer effect. SF1126 in combination with trastuzumab synergistically inhibits the growth of HER2-overexpressing breast cancers, including those that are trastuzumab resistant ${ }^{[61]}$. SF1126, either alone or in combination with anthracyclines, has profound anticancer effects in neuroblastoma and tumors with a highly activated PI3K-AktMDM2 pathway (Table 2). SF1126 inhibits tumor growth by blocking the production of PIP2 and PIP3. Ultimately, SF1126 prevents the conversion of inactive Rac1-GDP to active Rac1GTP, which deregulates actin cytoskeleton polymerization ${ }^{[62]}$.

\section{Achievements in clinical trials}

SF1126 has recently entered phase I clinical studies. The current phase I clinical trial of SF1126 in adults is at maximum dose $1,110 \mathrm{mg} / \mathrm{m}^{2}$ per dose (40 mg/ $\mathrm{kg}$ per dose) and shows minimal toxicity. SF1126 is in development in multiple phase

Table 1. Chemical nature, mode of action and clinical stage of different PI3K inhibitors.

\begin{tabular}{|c|c|c|c|c|}
\hline PI3K inhibitor & Chemical nature & Target & Clinical trial & Reference \\
\hline LY294002 & Flavonoid derivative & Pan PI3K & - & {$[57]$} \\
\hline Wortmanin & Furansteroid & PI3K, Polo like kinase & - & {$[171]$} \\
\hline PX-866 & Viridian derivative & $\mathrm{PI} 3 \mathrm{~K}$ & ॥ & Clinicaltrials.gov \\
\hline GDC-0941 & Morpholino derivative & Pan PI3K, mTOR & ॥ & [67] \\
\hline PKI-587 & Morpholino derivative with fused pyrimidines & Pan PI3K, mTOR & 1 & [78] \\
\hline NVP-BKM120 & Bismorphalino derivative & Pan PI3K, VPS34, mTOR, DNA-PK, and PI4K & 1 & {$[80]$} \\
\hline BGT-226 & Structure undisclosed & PI3K, mTOR & $1 / I I$ & [96] \\
\hline NVP-BEZ235 & Imidazoquinazoline derivative & Pan PI3K, mTOR & $1 / I I$ & [84] \\
\hline XL147 & Structure undisclosed & Class-I PI3K & 1 & [98] \\
\hline XL765 & Structure undisclosed & Class-I PI3K, DNAPK, mTOR & II & [98] \\
\hline
\end{tabular}

Table 2. Combinatorial effects of PI3K inhibitors on several cancers.

\begin{tabular}{|c|c|c|c|}
\hline PI3K inhibitors & Combination agents & Tumor types & Reference \\
\hline \multirow[t]{2}{*}{ SF1126 } & Trastuzumab & HER-2 overexpressing breast cancer & [60] \\
\hline & Doxorubicin & Neuroblastoma & {$[61]$} \\
\hline \multirow[t]{2}{*}{ GDC-0941 } & Trastuzumab and pertuzumab & Her-2 specific breast cancer & [69] \\
\hline & Doxorubicin & Breast and ovarian cancer & [70] \\
\hline \multirow[t]{6}{*}{ NVP-BEZ235 } & AZD6244 & Melanoma & {$[82]$} \\
\hline & RAD001 & Non-small cell lung cancer & {$[174]$} \\
\hline & & Neuroendocrine tumors & [175] \\
\hline & GSK2126458 & Breast cancer & [176] \\
\hline & Taxotere & Prostate cancer & [177] \\
\hline & PD0325901 & Glioma & [178] \\
\hline XL765 & Erlotinib & Solid tumor & \\
\hline
\end{tabular}




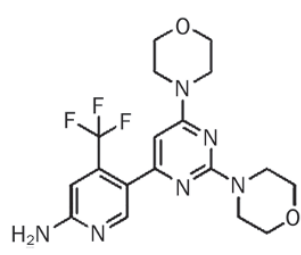

NVP-BKM120

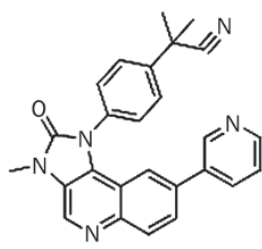

NVP-BEZ235

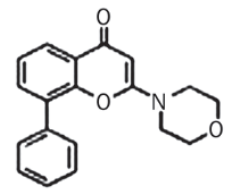

LY294002

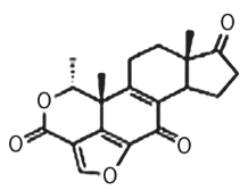

Wortmanin
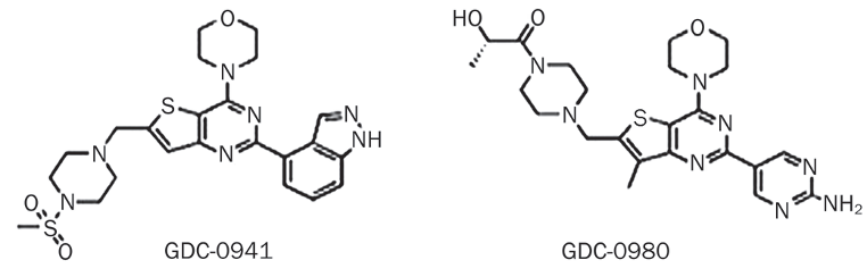

GDC-0980

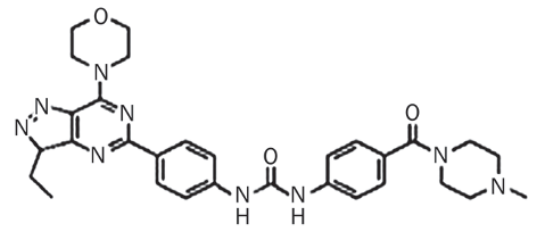

PKI-402

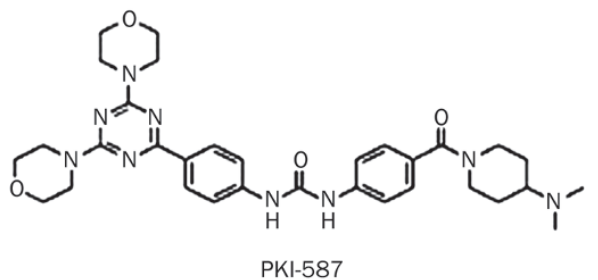

Figure 2. Chemical structure of the PI3K inhibitors.

I clinical trials as a single agent, and interim results have been presented recently from patients with solid tumors ${ }^{[62]}$ and multiple myelomas ${ }^{[63]}$. In an ongoing phase I dose escalation study in patients with solid tumors, SF1126 is administered weekly on days 1, 4 weekly by 90 -min IV infusions in cycles of 4 -week cycles. To date, 18 of 39 (46\%) of dosed patients showed stable disease as the best response, with a median duration of 13 weeks (range 8 to $64+$ weeks) and a mean duration of approximately 19 weeks. SF1126 is well tolerated, with the most common grade 1 adverse events being nausea, vomiting, diarrhea, fever, fatigue, chills, and pruritus. SF1126 is dual PI3K/mTOR inhibitor. However, SF1126 exerts its effects mainly as a PI3K inhibitor $^{[62]}$

Previous findings suggest that the morpholino group on the related quinazoline template of LY294002 was critical for the p110a inhibitory activity of LY294002. It was found that this morpholine oxygen helps in the hydrogen bonding interaction in the ATP pocket of both class of PI3K and $\mathrm{mTOR}^{[59]}$. Depending upon this phenomenon various analogs of LY294002 were discovered which interacts with PI3K and mTOR in a very similar manner ${ }^{[63]}$.

PX-866 is a semi-synthetic viridian derivative that potently and irreversibly inhibits PI3Ka, $\gamma$, and $\delta\left(\mathrm{IC}_{50}=5.5,9.0\right.$, and 2.7 $\mathrm{nmol} / \mathrm{L}$, respectively). PX-866 shows both increased selectivity towards PI3K $\beta\left(\mathrm{IC}_{50}>300 \mathrm{nmol} / \mathrm{L}\right)$ and improved stability and reduced hepatotoxicity, compared to wortmannin. The compound has also demonstrated antitumor activity in several human solid tumor models (eg, OvCar-3, HT-29, and A-549) when used alone $(2 \mathrm{mg} / \mathrm{kg}$, po) or in combination with chemotherapeutic or targeted anticancer agents (eg, paclitaxel or gefitinib) $^{[64]}$. PX-866 has also exhibited inhibitory effects on human glioblastoma by inducing autophagy and exploiting the aberrant PTEN/PI3K expression ${ }^{[65]}$. One of the major side effects of PX-866 is hyperglycemia. The data demonstrate that administration of PX-866 to SCID mice causes hyperglycemia with a decreased glucose tolerance. Recent findings have shown ways to circumvent this problem. Pioglitazone, which is a peroxisome proliferator-activated receptor gamma agonist, prevents the hyperglycemia caused by PX-866 without affecting its antitumor activity ${ }^{[66]}$. PX-866 had entered phase I clinical trials in 2008 and is currently in phase II clinical trials for prostate cancer treatment.

GDC-0941 is a morpholino derivative (Figure 2) that is a potent, selective, and orally available Pan-PI3K and dual pan$\mathrm{PI} 3 \mathrm{~K} / \mathrm{mTOR}$ inhibitor, which has recently entered into phase I clinical trials. GDC-0941 has a prominent inhibitory effect against all four isoforms of PI3K, but it is the most effective against p110a and p1108. GDC-0941 has selectivity against 228 kinases of the PI3K family. However, greater than 50\% inhibition occurs in the case of only two enzymes, Flt3 (59\% inhibition) and the human kinase TrkA (61\% inhibition) ${ }^{[67]}$. It has been previously shown that GDC-0941 has inhibitory effects on U87MG, PC3, SKOV-3, IGROV-1, Detroit 562, HCT116, SNUC2B, and LoVo cell lines with very low IC $_{50}$ values. GDC-0941 also inhibits U87MG glioblastoma and IGROV-1 human ovarian cancer xenograft models in athymic mice $^{[68]}$. GDC-0941 either alone or in combination with trastuzumab and pertuzumab inhibits HER-2 specific breast cancer effectively in vitro and in vivo ${ }^{[69]}$ (Table 2). In combination with DNA damaging agents, GDC-0941 has inhibitory effects on breast and ovarian cancer cells ${ }^{[70]}$ (Table 2). The drug also shows remarkable inhibitory effects on B-cell lymphomas in PTEN/LKB1 deficient mice. GDC-0941 suppresses the 
phosphorylation of Akt at Ser473 and Thr308, as well as the phosphorylation of PRAS 40 and ribosomal S6 kinase, which resides in the downstream of the PI3K pathway. However, GDC-0941 does not have a significant effect on the phosphorylation of 4E-Bp1. It is still unclear whether PTEN status affects the activity GDC-0941 in B-cell lymphomas ${ }^{[71]}$. Recently, it has been shown that the metastatic abilities of thyroid cancer cells are suppressed by GDC-0941. The mechanism of this inhibition is solely dependent upon the hypoxia-inducible factor-1a (HIF-1a). It has also been suggested that the anti-proliferative effects of GDC-0941 depend on PTEN status in thyroid can$\mathrm{cer}^{[72]}$, but the mechanism is still unclear. Thus, the role of PTEN status in the effectiveness of GDC-0941 is distinct for different cancer types. Further investigations are required to reach definitive conclusions regarding the effect of PTEN status on GDC-0941 efficacy.

Another morpholino derivative that acts as dual PI3K/ mTOR inhibitor and is going through phase II clinical trials is GDC-0980 (Figure 2). GDC-0980 is synthesized by substituting the indazole in GDC-0941 for a 2-aminopyrimidine ${ }^{[73]}$. This substitution also enhances the efficacy of mTOR inhibition. GDC-0980 has a very low $\mathrm{IC}_{50}(4.8 \mathrm{nmol} / \mathrm{L}$ for $\mathrm{p} 110 \mathrm{a} /$ $\mathrm{p} 85$ ). The drug shows great potency against a wide array of cell lines, including breast, prostate, and lung cancers; however, it demonstrates less activity in melanoma and pancreatic cancers, which is consistent with KRAS and BRAF acting as resistance markers in these tumors ${ }^{[74]}$. GDC-0980 shows inhibitory effects against human xenograft models, including PC3 and MCF-7 neo/HER2 xenografts and xenografts with activated PI3K, loss of LKB1 or PTEN. The drug also elicited an exposure-related decrease in PD biomarkers ${ }^{[74]}$.

\section{Current progress in clinical trials}

In phase I trials, to date it has been found that twelve patients have been enrolled in four successive dose-escalation cohorts with daily dose levels of 2, 4, 8, and 16 mg of GDC-0980. The most frequently reported adverse events were nausea (25\%), fatigue $(50 \%)$, diarrhea $(42 \%)$, and flatulence $(25 \%)$. No drugrelated grade 3 or higher events or DLT have been reported to date. Preliminary PK data revealed dose-proportional increases in $C_{\max }$ and AUC. Preliminary PD data show $>50 \%$ inhibition of pAkt levels assayed in PRP (relative to baseline) following a single dose of $8 \mathrm{mg}$ or higher GDC-0980. Potential signs of antitumor activity have been observed in one mesothelioma patient (previously treated with radiation and cisplatin/pemetrexed). This patient had a decrease in target lesions of $\sim 32 \%$, as measured by RECIST after one cycle of $8 \mathrm{mg}$ GDC0980 QD. A soft-tissue-sarcoma patient also had a decrease in tumor mean ( $\mathrm{SUV}_{\max }$ of $\sim 31 \%$ ), as assessed by FDG-PET after 2 weeks of $16 \mathrm{mg}$ GDC-0980 QD ${ }^{[75]}$. GDC-0941 and GDC-0980 will enter into phase 2 clinical trials with advanced and metastatic breast cancer patients (www.clinicaltrials.gov).

It has previously been reported that several morpholine group bearing fused pyrimidines, such as imidazolopyrimidines, pyrrolopyrimidines and triazolopyrimidines, act as PI3K/mTOR dual inhibitors. PKI-402 and PKI-587 are new additions to this group (Figure 2). PKI-402 is another dual $\mathrm{PI} 3 \mathrm{~K} / \mathrm{mTOR}$ inhibitor that behaves in an ATP competitive manner. PKI-402 exerts inhibitory effects against all of the isoforms of PI3K, including the E545K and H1047R PI3K-a mutants and mTOR. Analyses of the inhibitory effects of PKI402 against a panel of 236 human kinases showed a highly selective profile. However, only C-Raf and B-Raf (wild-type and V600E mutant) were inhibited by PKI-402 with a low $\mathrm{IC}_{50}$ value. PKI-402 has exhibited growth inhibition in vitro and in vivo against breast, brain, pancreas, and non-small cell lung cancer (NSCLC) cells ${ }^{[7]}$. The mechanism behind the inhibitory effects of PKI-402 was investigated in MDA-MB-361 cells. It was found out that PKI-402 inhibits MDA-MB-361 cell line growth in vitro and in vivo by inhibiting the phosphorylation of Akt at Ser473 and Thr308, as well as by inhibiting the downstream target molecules of Akt phosphorylation. PKI402 induces apoptosis in MDA-MB-361 cells by a caspase-3 dependent pathway ${ }^{[77]}$.

PKI-587 has a similar in vitro and in vivo profile to PKI-402. PKI-587 has broad in vivo efficacy in the MDA-MB-361, BT474, H1975, U87MG, and HCT116 tumor models ${ }^{[78]}$. PKI-587 has shown great potency against EGFR- and HER2-inhibitorresistant lung tumors. PKI-587 is less effective in HCT116 colon cancers bearing K-Ras and PIK3CA mutations. When combined with the MEK inhibitor PD0325901, PKI-587 shows enhanced efficacy in HCT116 cells in vitro and in vivo ${ }^{[7]}$.

NVP-BKM120, a bismorpholino derivative, inhibits a range of PI3K deregulated cell lines from a variety of tumor types, including glioblastoma and ovarian, breast, and prostate cancer. NVP-BKM120 inhibits all four isoforms of PI3K with the following low $\mathrm{IC}_{50}$ values: $0.052 \mu \mathrm{mol} / \mathrm{L}(\mathrm{p} 110 \mathrm{a}), 0.166$

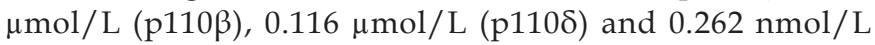
(p110ү). NVP-BKM120 has lower potency against class III and class IV PI3K. The biochemical activity of NVP-BKM120 was observed for the inhibition of VPS34, mTOR, DNAPK, and PI4K. The drug exerts antitumor activity against two models of PI3K/Akt pathway driven cancers: the A2780 ovarian carcinoma model and the U87MG glioma model, which carry a PTEN deletion ${ }^{[80]}$. It has also been observed that the inhibition of glioma cells by NVP-BKM120 depends upon the mutational status of p53. Wild-type p53 cells are more sensitive towards apoptosis than cells with mutated or deleted p53, which undergo mitotic catastrophe cell death ${ }^{[81]}$. NVP-BKM120 also enhances the efficacy of other antitumor agents in in vitro combination studies (Figure 2) ${ }^{[82]}$.

Another dual PI3K/mTOR inhibitor NVP-BEZ235, which is currently in phase I/II clinical trials, is the most effective small molecule inhibitor of PI3K to date. NVP-BEZ235 has an imidazoquinazoline moiety (Figure 2) that helps to mimic the $\mathrm{H}$-bond interactions between the adenine moiety of ATP and the hinge region using several binding modes, which inhibits the binding of ATP ${ }^{[83]}$. NVP-BEZ235 is a pan-PI3K inhibitor that acts against all of the isoforms of PI3K and PI3K mutants. Previous studies have demonstrated the efficacy of NVP-BEZ235 as an antitumor agent in vitro and in vivo in glioblastoma, multiple myeloma, melanoma, lymphoma, 
sarcoma, breast, lung, and ovarian cancer models ${ }^{[84-93]}$. In the case of colon cancer, NVP-BEZ23 decreases cellular proliferation and causes sustained inhibition of mTORC1 and mTORC2 with a transient PI3K blockade with no subsequent effect on apoptosis either in vitro or in vivo in a GEM model. The effect of NVP-BEZ235 does not depend on the mutational status of PIK3CA in in vitro CRC cell lines. The GEM model also suggests that treatment with NVP-BEZ23 causes tumor regression and a decrease in tumor angiogenesis ${ }^{[94]}$. NVP-BEZ235 shows remarkable efficacy in a wide array of cancer types in combination with several chemotherapeutic agents (Table 2).

BGT226, a dual PI3K/mTOR inhibitor, is currently in phase I/II clinical trials for solid tumor, breast cancer, and Cowden syndrome patients (www.clinicaltrial.gov). It has shown efficacy in inhibiting estrogen-deprived ER positive breast cancer cell lines, multiple myelomas and head and neck cancers ${ }^{[95-97]}$. The modes of inhibition by BGT226 vary in different types of cancer cell lines. BGT226 inhibits breast cancer by an apoptosis dependent manner which is solely dependent upon the PIK3CA mutational status ${ }^{[95]}$. But, on the contrary, BGT226 inhibits head and neck cancer in an apoptosis-independent manner. Instead of apoptosis, BGT226 induces autophagy, which is regulated by upregulation of the microtubule-associated protein light chain 3B-II and p62 degradation ${ }^{[97]}$.

XL-147 (structure not disclosed) is a low-molecular-weight, potent, orally bioavailable PI3K inhibitor that recently went into phase II clinical trials for advanced or recurrent endometrial cancer (www.clinicaltrials.gov). XL-147 generally inhibits the class I PI3K family of lipid kinases with a nanomolar range of $\mathrm{IC}_{50}$ values $^{[98]}$. XL-147 is active against class I PI3Ks $\left(\mathrm{IC}_{50}=39\right.$, 383,23 , and $36 \mathrm{nmol} / \mathrm{L}$ for $\mathrm{p} 110 \mathrm{\alpha}, \beta, \gamma$, and $\delta$, respectively) without inhibiting the kinase activity of $\mathrm{Vps} 34\left(\mathrm{IC}_{50}=6975\right.$ $\mathrm{nmol} / \mathrm{L})$, DNA-PK, or mTOR $\left(\mathrm{IC}_{50}>15000 \mathrm{nmol} / \mathrm{L}\right)^{[98,99]}$. XL-147 acts in an ATP competitive and reversible manner ${ }^{[98]}$. Preclinical studies suggest that XL-147 has a remarkable inhibitory effect on MCF-7 breast cancer cells and A549 lung adenocarcinoma cells ${ }^{[98]}$. The drug also induces striking tumor regression in breast, lung, ovarian, prostate, and glioma tumors ${ }^{[100]}$. In combination with several chemotherapeutic agents, XL147 has also shown tumor growth inhibition (Table 2).

$\mathrm{XL}-765$ is a dual PI3K/mTOR inhibitor with $\mathrm{IC}_{50} \mathrm{~s}$ in the low nanomolar range $\left(\mathrm{IC}_{50}=39,113,9\right.$, and $43 \mathrm{nmol} / \mathrm{L}$ for p110a, $\beta, \gamma$, and $\delta$, respectively). Unlike XL-147, XL-765 also inhibits DNA-PK $\left(\mathrm{IC}_{50}=150 \mathrm{nmol} / \mathrm{L}\right)$ and $\mathrm{mTOR}\left(\mathrm{IC}_{50}=157\right.$ $\mathrm{nmol} / \mathrm{L})^{[101,102]}$. Recent studies suggest that XL-765, in combination with autophagy-inducing agents, shows increased antitumor activity in pancreatic adenocarcinomas ${ }^{[103]}$. The combination of XL-765 and other chemotherapeutic agents is now undergoing a screening process and entering into clinical trials (Table 2). The clinical trial data suggest that there is inter-patient variability, with terminal half-life values that range from 2.5 to $8 \mathrm{~d}$ for XL-147 and 2 to $15 \mathrm{~h}$ for XL-765. Preliminary signs of exposure-dependent pharmacodynamic modulations (changes in plasma insulin levels) are observed at $30 \mathrm{mg} / 60 \mathrm{mg}$ for XL-147 and $15 \mathrm{mg} / 30 \mathrm{mg}$ bid for XL-765 ${ }^{[100]}$.

\section{Akt inhibitors}

The role of Akt in tumor initiation and progression has been discussed above. Overexpression and activation of Akt are often associated with resistance of tumors to chemotherapy or radiotherapy ${ }^{[104-106]}$. Current studies with a dominant negative Akt suggest that introducing a dominant negative Akt reduces Akt activity. These data suggest that Akt activity causes resistance against drug and radiation therapy ${ }^{[107,108]}$. Introduction of pan-Akt or Akt isoform-specific inhibitors exhibit great efficacy in inhibiting tumor growth.

Alkyl-phospholipids (APLs) are a heterogeneous group of unnatural lipids that have been shown to have anticancer activity. APLs are made up of two aliphatic side chains that are linked to glycerol phosphocholine by either an ether or thio-ether bond. Unlike the other anti-cancer agents described, APLs inhibit cancer by targeting cell membranes rather than $\mathrm{DNA}^{[109,110]}$. The rapid turnover and nonessential glycerol moiety of APLs restrict their use as anticancer agents. To overcome this problem, next generation molecules called alkylphosphocholines (APCs) have been synthesized.

APCs are derived from APLs by the removal of the glycerol group, which leads to increased stability of the compounds. This allows the APCs to integrate into the lipid bilayer of the cell membrane by accumulating in the lipid rafts where they disrupt the natural balance and metabolism of phospholipids, which in turn leads to alterations in membrane-signaling pathways that are associated with apoptosis ${ }^{[111]}$. Examples of anticancer APCs include the prototypic compound edelfosine and the novel drug octadecyl-(1,1-dimethyl-piperidinio-4-yl)phosphate (D-21266, Perifosine), which affect apoptotic signaling. Studies on malignantly transformed hematopoietic cell lines showed that APCs reduce the levels of phosphorylated Akt (Figure 3) ${ }^{[112]}$.

Perifosine is considered to be one of the first generation of Akt inhibitors. It is a alkylphospholipid derived from the compound miltefosine, which is also an APL that has antitumor activity to a lesser extent ${ }^{[113]}$ (Figure 3). Mechanistically, Perifosine exhibits antitumor activity by preventing Akt translocation to the cell membrane ${ }^{[114]}$. The drug has demonstrated antitumor effects in neuroblastoma, ovarian cancer, Waldenstrom's macroglobulinemia, medulloblastoma, kidney cancer, endometrial cancer, prostate cancer, myelogenous leukemia, multiple myeloma, squamous cell carcinoma, breast cancer, sarcoma, lung cancer, hepatocellular carcinoma, and other solid tumors ${ }^{[115-127]}$. With its success in preclinical models, Perifosine reached phase I and II trials for the treatment of only solid tumors, Waldenstrom's macroglobulinemia, and sarcoma ${ }^{[127-129]}$. In cases of relapsed or refracted Waldenstrom's macroglobulinemia, Perifosine resulted in at least a minimal response in $35 \%$ and stable disease in $54 \%$ of patients but had major side effects, including cytopenias and gastrointestinal toxicities. Despite its promising performance in the preclinical models, Perifosine monotherapy does not show efficacy in clinical trials. Disappointingly, it has been showing poor results in advanced or metastatic breast cancer, head and neck cancer, pancreatic adenocarcinoma, and metastatic mela- 


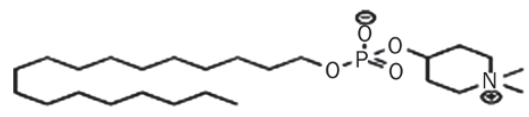

Perifosine

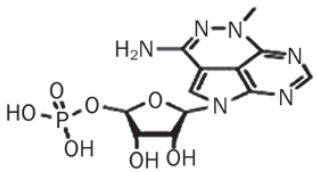

TCN/API2

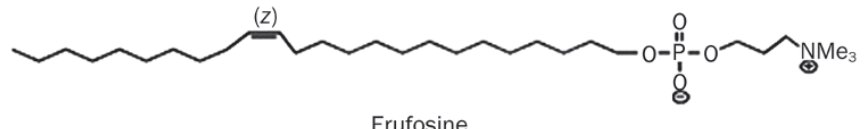

Erufosine

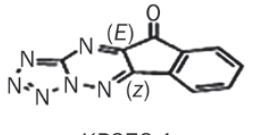

KP372-1

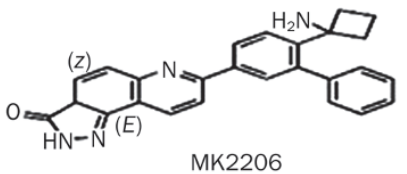

Figure 3. Chemical structure of Akt inhibitors.

noma patients. Recently, preclinical data have informed the attempts to use Perifosine for combination therapy (Table 3), Perifosine has had clinical success when used in combination regimens in metastatic colorectal cancer, relapsed or refractory multiple myeloma and glioma ${ }^{[130-132]}$. Perifosine in combination with paclitaxel leads to Akt/mTORC1 inhibition, along with a marked increase in ceramide and ROS generation and an increase in AMPK and JNK that results in apoptosis ${ }^{[133]}$. Perifosine induces caspase-dependent apoptosis and downregulates P-glycoprotein expression in multidrug-resistant human T-acute leukemia cells by a JNK-dependent mechanism. In multiple myeloma, the drug phosphorylates $\mathrm{Rb}^{[134]}$ and downregulates $\beta$-catenin and survivin ${ }^{[135]}$. Perifosine has been given Fast Track status by the FDA in these tumors and is currently in phase III clinical trials.

Erufosine, another APC compound, was introduced in late 1990. However, its lack of efficiency on the leukemia cell line has restricted its use ${ }^{[136]}$. Later, Erufosine was improved upon with a longer (22-carbon) chain containing cis-13-14 double bonds (Figure 3). Erufosine shows less hemolytic toxicity upon intravenous application and its cholinomimetic properties are less pronounced compared to perifosine ${ }^{[137]}$. It has been previously reported that Erufosine induced apoptosis in human astrocytoma and glioblastoma cell lines in vitro and affected rat C6 glioma tumor growth in vivo ${ }^{[138,139]}$. Erufosine induces apoptosis in glioma tumor by ROS generation and inhibits the mitochondrial respiratory chain, especially $\mathrm{F}_{1} \mathrm{~F}_{0^{-}}$ ATP-synthase ${ }^{[140]}$. Erufosine, either alone or in combination with other chemotherapeutic agents and ionic radiation, induces apoptosis in different kinds of cancer ${ }^{[141]}$ (Table 3). Erufosine combined with etoposide and cytarabine acts additively in acute myeloid leukemia ${ }^{[142]}$. Erufosine causes cell death in acute myeloid leukemia by JNK $1 / 2$ activation and ERK 1/2 dephosphorylation, leading to apoptosis ${ }^{[143]}$. Cytotoxic effects of Erufosine on chronic lymphocytic leukemia (CLL) and multiple myeloma have also been observed. However, depending upon Akt phosphorylation status, the mode of apoptosis induction is different ${ }^{[144,145]}$.

KP372-1, a triazinones derivative (Figure 3), inhibits proliferation and induces apoptosis in thyroid cancer, glioblastoma, squamous cell cancer, and acute myelogenous leukemia cell lines $^{[146-149]}$. It is also a PDK1 and FLT3 inhibitor that causes the inhibition of PKB activation through Ser473 phosphorylation, as well as downstream target phosphorylation, which reflects the non-selective mode of action. Recently KP372-1 was incorporated into nanoparticles and used in targeted drug-delivery systems ${ }^{[150]}$.

Triciribine (TCN/API-2) is a small-molecule Akt inhibitor that was invented in the early 1980 and 1990s. Despite showing efficacy in inhibiting the growth of several cancer cell lines, Triciribine was not widely used due to its poor performance in clinical trials ${ }^{[151]}$. This poor performance was due to the drug's minimal efficacy and poor toxicity profile, including hyperglycemia and hypertriglyceridemia at high doses. Recently, Triciribine was rediscovered from a chemical library of 1992 compounds in the NCI Diversity Set as an agent that was capable of inhibiting the growth of Akt2-transformed cell lines but not the parental NIH-3T3 cell line. The drug induces cell death by suppressing the phosphorylation of Akt on both Ser473 and Thr308 residue ${ }^{[152]}$. Triciribine suppresses epidermal growth factor-induced kinase activity and phosphoryla-

Table 3. Combinatorial effects of Akt inhibitors on cancer and progression into the clinical trial.

\begin{tabular}{|c|c|c|c|c|}
\hline AKT inhibitors & Combination agent & Tumor type & Clinical trial & Reference \\
\hline \multirow[t]{4}{*}{ Perifosine } & Capecitabine & Metastatic colorectal cancer & I & [130] \\
\hline & Bortezomib & Multiple myolema & I & [131] \\
\hline & Bortezomib+dexamethasone & Relapsed/refractory multiple myeloma & II & [131] \\
\hline & $\mathrm{CCl}-779$ & Glioma & I & [132] \\
\hline Erufosine & Etoposide & Acute myeloid leukemia & 1 & [141] \\
\hline MK2206 & Gefitinib & Glioma & I & {$[168]$} \\
\hline
\end{tabular}


tion of all three isoforms of Akt and results in EGF-mediated Akt recruitment to the plasma membrane. However, Triciribine does not inhibit Akt kinase activity in vitro and prevents the phosphorylation of Akt in intact cells ${ }^{[153]}$. After entering the cell, Triciribine is converted into the active metabolite TCN-P by adenosine kinase ${ }^{[154]}$. TCN-P binds with the PH domain of Akt and inhibits PIP3 to bind with it.

\section{Causes for inclusion in clinical trials}

One of the main problems for cancer therapeutics is immunoevasion, which occurs when the immune system cannot control tumor growth. The main cause of immunoevasion is supposed to be activation of Akt. TCN modulates immunoevasion efficiently in combination with the E7-specific vaccine ${ }^{[155]}$. TCN and TCN-P are currently being tested in clinical trials. They have been showing positive results in soft tissue sarcoma, colorectal cancer, tonsillar carcinoma and cervical squamous cell carcinoma patients ${ }^{[156,157]}$.

GSK690693 is a novel ATP competitive low-nanomolar pan-Akt kinase inhibitor (Figure 3) that belongs to the aminofurazan family, and it has $\mathrm{IC}_{50}$ values of 2,13 , and $9 \mathrm{nmol} / \mathrm{L}$ for Akt1, Akt2, and Akt 3, respectively ${ }^{[158]}$. It is highly selective towards Akt and 13 other kinases. Most of these kinases belong to the AGC kinase family, including the Akt kinases ${ }^{[159]}$. GSK690693 is found to be sensitive against the sixty-two hematologic tumor cell lines, including ALL, AML, CLL, CML, Burkitt's lymphoma, non-Hodgkin's lymphoma and Hodgkin's lymphoma cell lines, and induces apoptosis and growth inhibition $^{[160]}$. Recent studies using preclinical models suggest that GSK690693 had its greatest efficacy in delaying tumor progression in tumors and tumor derived cell lines with a high degree of Akt activation, including those with myristoylated constitutively active Akt or with PTEN loss ${ }^{[161]}$. However, in vivo testing of preclinical models suggests that GSK690693 exerts a moderate activity in solid tumor and ALL xenograft models $^{[162]}$.

MK2206 is an orally active allosteric Akt inhibitor (Figure 3). It shows equal potency toward two isoforms of Akt, purified recombinant human Akt1 $\left(\mathrm{IC}_{50}, 5 \mathrm{nmol} / \mathrm{L}\right)$ and Akt2 $\left(\mathrm{IC}_{50}, 12\right.$ $\mathrm{nmol} / \mathrm{L})$, but it is approximately five-fold less potent against human Akt3 $\left(\mathrm{IC}_{50}, 65 \mathrm{nmol} / \mathrm{L}\right)^{[163]}$. MK2206 shows great potency against several cancer cell lines harboring PIK3CA mutations ${ }^{[164,165]}$. In addition, MK-2206, in combination with other chemotherapeutic agents, exerts a greater potency against non-small cell lung cancer, glioma, breast, and ovarian carcinoma in both in vivo and in vitro models (Table 3$)^{[166-168]}$. MK-2206 helps in restoring the efficacy of sorefenib to induce apoptosis in sorefenib-resistant hepatocellular carcinomas ${ }^{[169]}$. MK-2206 is now in phase I clinical trials and is demonstrating efficacy with good tolerance levels ${ }^{[170]}$.

\section{Conclusion}

There is an impressive and increasing armamentarium of targeted agents that can inhibit the key components of the PI3KAkt pathway and many of these drugs are already in clinical trials. As discussed above, deregulation of these signaling cascades by mutation or overexpression of several receptors leads to aberrant activation of these intracellular cascades. This phenomenon is a frequent event in human tumors and provides unique opportunities for therapeutic approaches. Epidemiological data provide information regarding the different components and their roles in the PI3K-Akt pathway, which has allowed for the identification and development of clinical candidates that can control the irregular activation of these pathways. Currently, one of the biggest challenges for researchers designing kinase inhibitors is to identify structural features around the ATP-binding site of the targeted enzyme. Modern kinase inhibitors that are going into clinical trials demonstrate that small molecule inhibitors are highly successful in inducing anticancer effects. This is due to the strong interaction between the inhibitors and groups in the domain adjacent to the ATP-binding site. Despite the lack of complete specificity, with the exception of the PI3K/Akt inhibitors that are among the most selective inhibitors reported to date, the compounds in clinical trials have shown significant in vivo antitumor activities with no side effects in preclinical models. It is still unclear whether the selectivity of PI3K/Akt inhibitors, the potential therapeutic benefit, less side effects, greater drug tolerance, and concomitant inhibition of other off-targets and downstream targets will be beneficial in the treatment of cancer. It is imperative that clinical reagents with maximum efficacy and minimum lethal dose and side effects be carefully chosen. This will allow therapies to be made swiftly available for all suitable candidates. We can only hope that novel and safe targeted anticancer agents will come from these drug discovery efforts ${ }^{[171-178]}$.

\section{Acknowledgements}

This study was supported by grants from the Department of Biotechnology and the Department of Science and Technology, the University Grant Commission (UGC), India.

\section{References}

1 Vivanco I, Sawyers CL. The phosphatidylinositol 3-Kinase AKT pathway in human cancer. Nat Rev Cancer 2002; 2: 489-501.

2 Vanhaesebroeck B, Waterfield MD. Signaling by distinct classes of phosphoinositide 3-kinases. Exp Cell Res 1999; 253: 239-54.

3 Fruman DA, Meyers RE, Cantley LC. Phosphoinositide kinases. Annu Rev Biochem 1998; 67: 481-507.

4 Jimenez $\mathrm{C}$, Hernandez C, Pimentel B, Carrera AC. The p85 regulatory subunit controls sequential activation of phosphoinositide 3-kinase by Tyr kinases and Ras. J Biol Chem 2002; 277: 41556-62.

5 Philp AJ, Campbell IG, Leet C, Vincan E, Rockman SP, Whitehead RH, et al. The phosphatidylinositol 3'-kinase p85alpha gene is an oncogene in human ovarian and colon tumors. Cancer Res 2001; 61: 7426-9.

6 Cantley LC. The phosphoinositide 3-kinase pathway. Science 2002; 296: 1655-7.

7 Alessi DR, James SR, Downes CP, Holmes AB, Gaffney PR, Reese CB, et al. Characterization of a 3-phosphoinositide-dependent protein kinase which phosphorylates and activates protein kinase Balpha. Curr Biol 1997; 7: 261-9.

8 Fresno Vara JA, Casado E, de Castro J, Cejas P, Belda-Iniesta C, 
Gonzalez-Baron M. PI3K/Akt signalling pathway and cancer. Cancer Treat Rev 2004; 30: 193-204.

9 Olayioye MA, Neve RM, Lane HA, Hynes NE. The ErbB signaling network: receptor heterodimerization in development and cancer. EMBO J 2000; 19: 3159-67.

10 Siegel PM, Ryan ED, Cardiff RD, Muller WJ. Elevated expression of activated forms of Neu/ErbB-2 and ErbB-3 are involved in the induction of mammary tumors in transgenic mice: implications for human breast cancer. EMBO J 1999; 18: 2149-64.

11 Prigent SA, Gullick WJ. Identification of c-erbB-3 binding sites for phosphatidylinositol 3'-kinase and SHC using an EGF receptor/ c-erbB-3 chimera. EMBO J 1994; 13: 2831-41.

12 Chitnis MM, Yuen JS, Protheroe AS, Pollak M, Macaulay VM. The type 1 insulin-like growth factor receptor pathway. Clin Cancer Res 2008; 14: 6364-70.

13 Belfiore A, Malaguarnera R. Insulin receptor and cancer. Endocr Relat Cancer 2011; 18: R125-47.

14 Gallagher EJ, LeRoith D. The proliferating role of insulin and insulinlike growth factors in cancer. Trends Endocrinol Metab 2010; 21 : 610-8.

15 Kim SY, Toretsky JA, Scher D, Helman LJ. The role of IGF-1R in pediatric malignancies. Oncologist 2009; 14: 83-91.

16 Surmacz E. Growth factor receptors as therapeutic targets: strategies to inhibit the insulin-like growth factor I receptor. Oncogene 2003; 22: 6589-97.

17 Wang $\mathrm{H}$, Yin Y, Li W, Zhao X, Yu Y, Zhu J, et al. Over-expression of PDGFR-beta promotes PDGF-induced proliferation, migration, and angiogenesis of EPCs through PI3K/Akt signaling pathway. PLoS One 2012; 7: e30503.

18 Heldin $\mathrm{CH}$. Simultaneous induction of stimulatory and inhibitory signals by PDGF. FEBS Lett 1997; 410: 17-21.

19 Heldin $\mathrm{CH}$, Ostman A, Ronnstrand L. Signal transduction via plateletderived growth factor receptors. Biochim Biophys Acta 1998; 1378 : F79-113.

20 Ferrara N. Vascular endothelial growth factor as a target for anticancer therapy. Oncologist 2004; 9: 2-10.

21 Abid MR, Guo S, Minami T, Spokes KC, Ueki K, Skurk C, et al. Vascular endothelial growth factor activates PI3K/Akt/forkhead signaling in endothelial cells. Arterioscler Thromb Vasc Biol 2004; 24: 294-300.

22 Kowanetz M, Ferrara N. Vascular endothelial growth factor signaling pathways: therapeutic perspective. Clin Cancer Res 2006; 12: 5018-22.

23 Shalaby F, Rossant J, Yamaguchi TP, Gertsenstein M, Wu XF, Breitman $\mathrm{ML}$, et al. Failure of blood-island formation and vasculogenesis in Flk-1-deficient mice. Nature 1995; 376: 62-6.

24 Takahashi T, Yamaguchi S, Chida K, Shibuya M. A single autophosphorylation site on KDR/FIK-1 is essential for VEGF-A-dependent activation of PLC-gamma and DNA synthesis in vascular endothelial cells. EMBO J 2001; 20: 2768-78.

25 Holmqvist K, Cross MJ, Rolny C, Hagerkvist R, Rahimi N, Matsumoto $\mathrm{T}$, et al. The adaptor protein shb binds to tyrosine 1175 in vascular endothelial growth factor (VEGF) receptor-2 and regulates VEGFdependent cellular migration. J Biol Chem 2004; 279: 22267-75.

26 Fujio Y, Walsh K. Akt mediates cytoprotection of endothelial cells by vascular endothelial growth factor in an anchorage-dependent manner. J Biol Chem 1999; 274: 16349-54.

27 Gerber HP, McMurtrey A, Kowalski J, Yan M, Keyt BA, Dixit V, et al. Vascular endothelial growth factor regulates endothelial cell survival through the phosphatidylinositol 3'-kinase/Akt signal transduction pathway. Requirement for Flk-1/KDR activation. J Biol Chem 1998;
273: 30336-43.

28 Ferguson SS. Evolving concepts in G protein-coupled receptor endocytosis: the role in receptor desensitization and signaling. Pharmacol Rev 2001; 53: 1-24.

29 Vanhaesebroeck B, Guillermet-Guibert J, Graupera M, Bilanges B. The emerging mechanisms of isoform-specific PI3K signalling. Nat Rev Mol Cell Biol 2010; 11: 329-41.

30 Guillermet-Guibert J, Bjorklof K, Salpekar A, Gonella C, Ramadani F, Bilancio A, et al. The p110beta isoform of phosphoinositide 3-kinase signals downstream of $\mathrm{G}$ protein-coupled receptors and is functionally redundant with p110gamma. Proc Natl Acad Sci U S A 2008; 105: 8292-7.

31 Campbell IG, Russell SE, Choong DY, Montgomery KG, Ciavarella ML, Hooi CS, et al. Mutation of the PIK3CA gene in ovarian and breast cancer. Cancer Res 2004; 64: 7678-81.

32 Samuels Y, Velculescu VE. Oncogenic mutations of PIK3CA in human cancers. Cell Cycle 2004; 3: 1221-4.

33 Chalhoub N, Baker SJ. PTEN and the PI3-kinase pathway in cancer. Annu Rev Pathol 2009; 4: 127-50.

34 Kang S, Bader AG, Vogt PK. Phosphatidylinositol 3-kinase mutations identified in human cancer are oncogenic. Proc Natl Acad Sci U S A 2005; 102: 802-7.

35 Simpson L, Parsons R. PTEN: life as a tumor suppressor. Exp Cell Res 2001; 264: 29-41.

36 Nicholson KM, Anderson NG. The protein kinase B/Akt signalling pathway in human malignancy. Cell Signal 2002; 14: 381-95.

37 Bozulic L, Hemmings BA. PIKKing on PKB: regulation of PKB activity by phosphorylation. Curr Opin Cell Biol 2009; 21: 256-61.

38 Huang J, Manning BD. A complex interplay between Akt, TSC2 and the two mTOR complexes. Biochem Soc Trans 2009; 37: 217-22.

39 Hers I, Vincent EE, Tavare JM. Akt signalling in health and disease. Cell Signal 2011; 23: 1515-27.

40 Yang WL, Wu CY, Wu J, Lin HK. Regulation of Akt signaling activation by ubiquitination. Cell Cycle 2010; 9: 487-97.

41 Konishi H, Matsuzaki H, Tanaka M, Takemura Y, Kuroda S, Ono Y, et al. Activation of protein kinase B (Akt/RAC-protein kinase) by cellular stress and its association with heat shock protein Hsp27. FEBS Lett 1997; 410: 493-8.

42 van Gorp AG, Pomeranz KM, Birkenkamp KU, Hui RC, Lam EW, Coffer PJ. Chronic protein kinase B (PKB/c-akt) activation leads to apoptosis induced by oxidative stress-mediated Foxo3a transcriptional upregulation. Cancer Res 2006; 66: 10760-9.

43 Bellacosa A, de Feo D, Godwin AK, Bell DW, Cheng JQ, Altomare DA, et al. Molecular alterations of the AKT2 oncogene in ovarian and breast carcinomas. Int J Cancer 1995; 64: 280-5.

44 Cheng JQ, Ruggeri B, Klein WM, Sonoda G, Altomare DA, Watson DK, et al. Amplification of AKT2 in human pancreatic cells and inhibition of AKT2 expression and tumorigenicity by antisense RNA. Proc Natl Acad Sci U S A 1996; 93: 3636-41.

45 Ballif BA, Roux PP, Gerber SA, MacKeigan JP, Blenis J, Gygi SP. Quantitative phosphorylation profiling of the ERK/p90 ribosomal S6 kinase-signaling cassette and its targets, the tuberous sclerosis tumor suppressors. Proc Natl Acad Sci U S A 2005; 102: 667-72.

46 Biggs WH 3rd, Meisenhelder J, Hunter T, Cavenee WK, Arden KC. Protein kinase B/Akt-mediated phosphorylation promotes nuclear exclusion of the winged helix transcription factor FKHR1. Proc Natl Acad Sci U S A 1999; 96: 7421-6.

47 Brunet A, Bonni A, Zigmond MJ, Lin MZ, Juo P, Hu LS, et al. Akt promotes cell survival by phosphorylating and inhibiting a Forkhead transcription factor. Cell 1999; 96: 857-68.

48 Romashkova JA, Makarov SS. NF-kappaB is a target of AKT in anti- 
apoptotic PDGF signalling. Nature 1999; 401: 86-90.

49 Ozes ON, Mayo LD, Gustin JA, Pfeffer SR, Pfeffer LM, Donner DB. NFkappaB activation by tumour necrosis factor requires the Akt serinethreonine kinase. Nature 1999; 401: 82-5.

50 del Peso L, Gonzalez-Garcia M, Page C, Herrera R, Nunez G. Interleukin-3-induced phosphorylation of BAD through the protein kinase Akt. Science 1997; 278: 687-9.

51 Datta SR, Dudek H, Tao X, Masters S, Fu H, Gotoh Y, et al. Akt phosphorylation of BAD couples survival signals to the cell-intrinsic death machinery. Cell 1997; 91: 231-41.

52 Ferkey DM, Kimelman D. GSK-3: new thoughts on an old enzyme. Dev Biol 2000; 225: 471-9.

53 Kim L, Kimmel AR. GSK3, a master switch regulating cell-fate specification and tumorigenesis. Curr Opin Genet Dev 2000; 10 : 508-14.

54 Castaneda CA, Cortes-Funes H, Gomez HL, Ciruelos EM. The phosphatidyl inositol 3-kinase/AKT signaling pathway in breast cancer. Cancer Metastasis Rev 2010; 29: 751-9.

55 Wymann MP, Bulgarelli-Leva G, Zvelebil MJ, Pirola L, Vanhaesebroeck $B$, Waterfield MD, et al. Wortmannin inactivates phosphoinositide 3-kinase by covalent modification of Lys-802, a residue involved in the phosphate transfer reaction. Mol Cell Biol 1996; 16: 1722-33.

56 Wetzker R, Rommel C. Phosphoinositide 3-kinases as targets for therapeutic intervention. Curr Pharm Des 2004; 10: 1915-22.

57 Semba S, Itoh N, Ito M, Harada M, Yamakawa M. The in vitro and in vivo effects of 2-(4-morpholinyl)-8-phenyl-chromone (LY294002), a specific inhibitor of phosphatidylinositol 3'-kinase, in human colon cancer cells. Clin Cancer Res 2002; 8: 1957-63.

58 Fan QW, Specht KM, Zhang C, Goldenberg DD, Shokat KM, Weiss WA. Combinatorial efficacy achieved through two-point blockade within a signaling pathway - a chemical genetic approach. Cancer Res 2003; 63: 8930-8.

59 Vlahos CJ, Matter WF, Hui KY, Brown RF. A specific inhibitor of phosphatidylinositol 3-kinase, 2-(4-morpholinyl)-8-phenyl-4H-1benzopyran-4-one (LY294002). J Biol Chem 1994; 269: 5241-8.

60 Zhang YJ, Duan Y, Zheng XF. Targeting the mTOR kinase domain: the second generation of mTOR inhibitors. Drug Discov Today 2011; 16 : 325-31.

61 Ozbay T, Durden DL, Liu T, O'Regan RM, Nahta R. In vitro evaluation of pan-PI3-kinase inhibitor SF1126 in trastuzumab-sensitive and trastuzumab-resistant HER2-over-expressing breast cancer cells. Cancer Chemother Pharmacol 2010; 65: 697-706.

62 Peirce SK, Findley HW, Prince C, Dasgupta A, Cooper T, Durden DL. The PI-3 kinase-Akt-MDM2-survivin signaling axis in high--risk neuroblastoma: a target for PI-3 kinase inhibitor intervention. Cancer Chemother Pharmacol 2011; 68: 325-35.

63 Hayakawa M, Kaizawa H, Moritomo H, Koizumi T, Ohishi T, Okada $\mathrm{M}$, et al. Synthesis and biological evaluation of 4-morpholino-2phenylquinazolines and related derivatives as novel PI3 kinase p110alpha inhibitors. Bioorg Med Chem 2006; 14: 6847-58.

64 Ihle NT, Williams R, Chow S, Chew W, Berggren MI, Paine-Murrieta G, et al. Molecular pharmacology and antitumor activity of PX-866, a novel inhibitor of phosphoinositide-3-kinase signaling. Mol Cancer Ther 2004; 3: 763-72.

65 Koul D, Shen R, Kim YW, Kondo Y, Lu Y, Bankson J, et al. Cellular and in vivo activity of a novel PI3K inhibitor, PX-866, against human glioblastoma. Neuro Oncol 2010; 12: 559-69.

66 Ihle NT, Lemos R, Schwartz D, Oh J, Halter RJ, Wipf P, et al. Peroxisome proliferator-activated receptor gamma agonist pioglitazone prevents the hyperglycemia caused by phosphatidylinositol 3-kinase pathway inhibition by PX-866 without affecting antitumor activity.
Mol Cancer Ther 2009; 8: 94-100.

67 Folkes AJ, Ahmadi K, Alderton WK, Alix S, Baker SJ, Box G, et al. The identification of 2-(1H-indazol-4-yl)-6-(4-methanesulfonyl-piperazin1-ylmethyl)-4-morpholin-4-yl-thieno[3,2-d]pyrimidine (GD-0941) as a potent, selective, orally bioavailable inhibitor of class I PI3 kinase for the treatment of cancer. J Med Chem 2008; 51: 5522-32.

68 Raynaud FI, Eccles SA, Patel S, Alix S, Box G, Chuckowree I, et al. Biological properties of potent inhibitors of class I phosphatidylinositide 3-kinases: from Pl-103 through PI-540, PI-620 to the oral agent GDC-0941. Mol Cancer Ther 2009; 8: 1725-38.

69 Yao E, Zhou W, Lee-Hoeflich ST, Truong T, Haverty PM, EasthamAnderson J, et al. Suppression of HER2/HER3-mediated growth of breast cancer cells with combinations of GDC-0941 PI3K inhibitor, trastuzumab, and pertuzumab. Clin Cancer Res 2009; 15: 4147-56.

70 Wallin JJ, Guan J, Prior WW, Edgar KA, Kassees R, Sampath D, et al. Nuclear phospho-Akt increase predicts synergy of PI3K inhibition and doxorubicin in breast and ovarian cancer. Sci Transl Med 2010; 2: 48 ra66.

71 Garcia-Martinez JM, Wullschleger S, Preston G, Guichard S, Fleming $\mathrm{S}$, Alessi DR, et al. Effect of PI3K- and mTOR-specific inhibitors on spontaneous B-cell follicular lymphomas in PTEN/LKB1-deficient mice. Br J Cancer 2011; 104: 1116-25.

72 Burrows N, Babur M, Resch J, Ridsdale S, Mejin M, Rowling EJ, et al. GDC-0941 inhibits metastatic characteristics of thyroid carcinomas by targeting both the phosphoinositide-3 kinase (PI3K) and hypoxiainducible factor-1alpha (HIF-1alpha) pathways. J Clin Endocrinol Metab 2011; 96: E1934-43.

73 Sutherlin DP, Bao L, Berry M, Castanedo G, Chuckowree I, Dotson $\mathrm{J}$, et al. Discovery of a potent, selective, and orally available class I phosphatidylinositol 3-kinase (PI3K)/mammalian target of rapamycin (mTOR) kinase inhibitor (GDC-0980) for the treatment of cancer. J Med Chem 2011; 54: 7579-87.

74 Wallin JJ, Edgar KA, Guan J, Berry M, Prior WW, Lee L, et al. GDC0980 is a novel class I PI3K/mTOR kinase inhibitor with robust activity in cancer models driven by the PI3K pathway. Mol Cancer Ther 2011; 10: 2426-36.

75 Dolly S. A first-in-human, phase I study to evaluate the dual PI3K/ mTOR inhibitor GDC-0980 administered QD in patients with advanced solid tumors or non-Hodgkin's lymphoma. ASCO Annual Meeting 2010

76 Dehnhardt CM, Venkatesan AM, Delos Santos E, Chen Z, Santos $\mathrm{O}$, Ayral-Kaloustian S, et al. Lead optimization of N-3-substituted 7-morpholinotriazolopyrimidines as dual phosphoinositide 3-kinase/ mammalian target of rapamycin inhibitors: discovery of PKI-402. J Med Chem 2010; 53: 798-810.

77 Mallon R, Hollander I, Feldberg L, Lucas J, Soloveva V, Venkatesan A, et al. Antitumor efficacy profile of PKI-402, a dual phosphatidylinositol 3-kinase/mammalian target of rapamycin inhibitor. Mol Cancer Ther 2010; 9: 976-84.

78 Venkatesan AM, Dehnhardt CM, Delos Santos E, Chen Z, Dos Santos O, Ayral-Kaloustian S, et al. Bis(morpholino-1,3,5-triazine) derivatives: potent adenosine $5^{\prime}$-triphosphate competitive phosphatidylinositol-3-kinase/mammalian target of rapamycin inhibitors: discovery of compound 26 (PKI-587), a highly efficacious dual inhibitor. J Med Chem 2010; 53: 2636-45.

79 Mallon R, Feldberg LR, Lucas J, Chaudhary I, Dehnhardt C, Santos ED, et al. Antitumor efficacy of PKI-587, a highly potent dual PI3K/ mTOR kinase inhibitor. Clin Cancer Res 2011; 17: 3193-203.

80 Burger MT, Pecchi S, Wagman A, Ni ZJ, Knapp M, Hendrickson T, et al. Identification of NVP-BKM120 as a potent, selective, orally bioavailable class I PI3 kinase inhibitor for treating cancer. ACS Med 
Chem Lett 2011; 2:774-9.

81 Koul D, Fu J, Shen R, Lafortune TA, Wang S, Tiao N, et al. Antitumor activity of NVP-BKM120 - a selective pan class 1 PI3 Kinase inhibitor showed differential forms of cell death based on P53 status of glioma cells. Clin Cancer Res 2012; 18:184-95.

82 Aziz SA, Jilaveanu LB, Zito C, Camp RL, Rimm DL, Conrad P, et al. Vertical targeting of the phosphatidylinositol-3 kinase pathway as a strategy for treating melanoma. Clin Cancer Res 2010; 16: 602939.

83 Stauffer F, Maira SM, Furet P, Garcia-Echeverria C. Imidazo[4,5-c] quinolines as inhibitors of the PI3K/PKB-pathway. Bioorg Med Chem Lett 2008; 18: 1027-30.

84 Santiskulvong C, Konecny GE, Fekete M, Chen KY, Karam A, Mulholland $\mathrm{D}$, et al. Dual targeting of phosphoinositide 3-kinase and mammalian target of rapamycin using NVP-BEZ235 as a novel therapeutic approach in human ovarian carcinoma. Clin Cancer Res 2011; 17: 2373-84.

85 Serra V, Markman B, Scaltriti M, Eichhorn PJ, Valero V, Guzman M, et al. NVP-BEZ235, a dual PI3K/mTOR inhibitor, prevents PI3K signaling and inhibits the growth of cancer cells with activating PI3K mutations. Cancer Res 2008; 68: 8022-30.

86 Liu TJ, Koul D, LaFortune T, Tiao N, Shen RJ, Maira SM, et al. NVPBEZ235, a novel dual phosphatidylinositol 3-kinase/mammalian target of rapamycin inhibitor, elicits multifaceted antitumor activities in human gliomas. Mol Cancer Ther 2009; 8: 2204-10.

87 McMillin DW, Ooi M, Delmore J, Negri J, Hayden P, Mitsiades N, et al. Antimyeloma activity of the orally bioavailable dual phosphatidylinositol 3-kinase/mammalian target of rapamycin inhibitor NVP-BEZ235. Cancer Res 2009; 69: 5835-42.

88 Marone R, Erhart D, Mertz AC, Bohnacker T, Schnell C, Cmiljanovic $\mathrm{V}$, et al. Targeting melanoma with dual phosphoinositide 3-kinase/ mammalian target of rapamycin inhibitors. Mol Cancer Res 2009; 7: 601-13.

89 Baumann P, Mandl-Weber S, Oduncu F, Schmidmaier R. The novel orally bioavailable inhibitor of phosphoinositol-3-kinase and mammalian target of rapamycin, NVP-BEZ235, inhibits growth and proliferation in multiple myeloma. Exp Cell Res 2009; 315: 485-97.

90 Konstantinidou G, Bey EA, Rabellino A, Schuster K, Maira MS, Gazdar $\mathrm{AF}$, et al. Dual phosphoinositide 3-kinase/mammalian target of rapamycin blockade is an effective radiosensitizing strategy for the treatment of non-small cell lung cancer harboring K-RAS mutations. Cancer Res 2009; 69: 7644-52.

91 Brachmann SM, Hofmann I, Schnell C, Fritsch C, Wee S, Lane H, et al. Specific apoptosis induction by the dual PI3K/mTor inhibitor NVPBEZ235 in HER2 amplified and PIK3CA mutant breast cancer cells. Proc Natl Acad Sci U S A 2009; 106: 22299-304.

92 Manara MC, Nicoletti G, Zambelli D, Ventura S, Guerzoni C, Landuzzi L, et al. NVP-BEZ235 as a new therapeutic option for sarcomas. Clin Cancer Res 2010; 16: 530-40.

93 Bhatt AP, Bhende PM, Sin SH, Roy D, Dittmer DP, Damania B. Dual inhibition of PI3K and $\mathrm{mTOR}$ inhibits autocrine and paracrine proliferative loops in PI3K/Akt/mTOR-addicted lymphomas. Blood 2010; 115: 4455-63.

94 Roper J, Richardson MP, Wang WV, Richard LG, Chen W, Coffee EM, et al. The dual PI3K/mTOR inhibitor NVP-BEZ235 induces tumor regression in a genetically engineered mouse model of PIK3CA wildtype colorectal cancer. PLoS One 2011; 6: e25132.

95 Sanchez CG, Ma CX, Crowder RJ, Guintoli T, Phommaly C, Gao F, et al. Preclinical modeling of combined phosphatidylinositol-3-kinase inhibition with endocrine therapy for estrogen receptor-positive breast cancer. Breast Cancer Res 2011; 13: R21.
96 Baumann P, Schneider L, Mandl-Weber S, Oduncu F, Schmidmaier R. Simultaneous targeting of PI3K and mTOR with NVP-BGT226 is highly effective in multiple myeloma. Anticancer Drugs 2012; 23: 131-8.

97 Chang KY, Tsai SY, Wu CM, Yen CJ, Chuang BF, Chang JY. Novel phosphoinositide 3-Kinase/mTOR dual inhibitor, NVP-BGT226, displays potent growthiinhibitory activity against human head and neck cancer cells in vitro and in vivo. Clin Cancer Res 2011; 17: 7116-26.

98 Shapiro Gl, Edelman G, Calvo E, Aggarwal SK, Laird AD. Targeting aberrant PI3K pathway signaling with XL147, a potent, selective, and orally bioavailable PI3K inhibitor. Proc 97th Annu Meet AACR; 2007 Apr 14-18; Los Angeles, CA. Abstract C205.

99 Foster P. Potentiating the antitumor effects of chemotherapy with the selective PI3K inhibitor XL147; 19th AACR-NCI-EORTC Meeting; San Francisco, CA. 2007.

100 Garcia-Echeverria C. Protein and lipid kinase inhibitors as targeted anticancer agents of the Ras/Raf/MEK and PI3K/PKB pathways. Purinergic Signal 2009; 5: 117-25.

101 Laird D. XL765 targets tumor growth, survival, and angiogenesis in preclinical models by dual inhibition of PI3K and mTOR (abstract B250). EORTC meeting 2007.

102 Patnaik A, LoRusso P, Tabernero JA, Laird D, Aggarwal S, Papadopoulos K. Biomarker development for XL765, a potent and selective oral dual inhibitor of PI3K and mTOR currently being administered to patients in a phase I clinical trial (abstract B265). EORTC Meeting 2007.

103 Mirzoeva OK, Hann B, Hom YK, Debnath J, Aftab D, Shokat K, et al. Autophagy suppression promotes apoptotic cell death in response to inhibition of the PI3K-mTOR pathway in pancreatic adenocarcinoma. J Mol Med (Berl) 2011; 89: 877-89.

104 Winograd-Katz SE, Levitzki A. Cisplatin induces PKB/Akt activation and p38 (MAPK) phosphorylation of the EGF receptor. Oncogene 2006; 25: 7381-90.

105 Liu LZ, Zhou XD, Qian G, Shi X, Fang J, Jiang BH. AKT1 amplification regulates cisplatin resistance in human lung cancer cells through the mammalian target of rapamycin/p70S6K1 pathway. Cancer Res 2007; 67: 6325-32.

106 Bellacosa A, Kumar CC, Di Cristofano A, Testa JR. Activation of AKT kinases in cancer: implications for therapeutic targeting. Adv Cancer Res 2005; 94: 29-86.

107 Clark AS, West K, Streicher S, Dennis PA. Constitutive and inducible Akt activity promotes resistance to chemotherapy, trastuzumab, or tamoxifen in breast cancer cells. Mol Cancer Ther 2002; 1: 707-17.

108 Brognard J, Clark AS, Ni Y, Dennis PA. Akt/protein kinase B is constitutively active in non-small cell lung cancer cells and promotes cellular survival and resistance to chemotherapy and radiation. Cancer Res 2001; 61: 3986-97.

109 Gajate C, Mollinedo F. Biological activities, mechanisms of action and biomedical prospect of the antitumor ether phospholipid ET-18$\mathrm{OCH}(3)$ (edelfosine), a proapoptotic agent in tumor cells. Curr Drug Metab 2002; 3: 491-525.

110 Mollinedo F, Fernandez-Luna JL, Gajate C, Martin-Martin B, Benito A, Martinez-Dalmau R, et al. Selective induction of apoptosis in cancer cells by the ether lipid ET-18- $\mathrm{OCH}_{3}$ (Edelfosine): molecular structure requirements, cellular uptake, and protection by $\mathrm{Bcl}-2$ and $\mathrm{Bcl}-\mathrm{X}(\mathrm{L})$. Cancer Res 1997; 57: 1320-8.

111 van der Luit AH, Vink SR, Klarenbeek JB, Perrissoud D, Solary E, Verheij M, et al. A new class of anticancer alkylphospholipids uses lipid rafts as membrane gateways to induce apoptosis in lymphoma cells. Mol Cancer Ther 2007; 6: 2337-45.

112 Zaharieva MM, Konstantinov SM, Pilicheva B, Karaivanova M, Berger 
MR. Erufosine: a membrane targeting antineoplastic agent with signal transduction modulating effects. Ann N Y Acad Sci 2007; 1095: 182-92.

113 Hilgard P, Klenner T, Stekar J, Nossner G, Kutscher B, Engel J. D-21266, a new heterocyclic alkylphospholipid with antitumour activity. Eur J Cancer 1997; 33: 442-6.

114 Kondapaka SB, Singh SS, Dasmahapatra GP, Sausville EA, Roy KK. Perifosine, a novel alkylphospholipid, inhibits protein kinase B activation. Mol Cancer Ther 2003; 2: 1093-103.

$115 \mathrm{Li}$ Z, Tan F, Liewehr DJ, Steinberg SM, Thiele CJ. In vitro and in vivo inhibition of neuroblastoma tumor cell growth by AKT inhibitor perifosine. J Natl Cancer Inst 2010; 102: 758-70.

116 Hennessy BT, Lu Y, Poradosu E, Yu Q, Yu S, Hall H, et al. Pharmacodynamic markers of perifosine efficacy. Clin Cancer Res 2007; 13: 7421-31.

117 Leleu X, Jia X, Runnels J, Ngo HT, Moreau AS, Farag M, et al. The Akt pathway regulates survival and homing in Waldenstrom macroglobulinemia. Blood 2007; 110: 4417-26.

118 Kumar A, Fillmore HL, Kadian R, Broaddus WC, Tye GW, Van Meter TE. The alkylphospholipid perifosine induces apoptosis and p21-mediated cell cycle arrest in medulloblastoma. Mol Cancer Res 2009; 7: 1813-21.

119 Porta C, Figlin RA. Phosphatidylinositol-3-kinase/Akt signaling pathway and kidney cancer, and the therapeutic potential of phosphatidylinositol-3-kinase/Akt inhibitors. J Urol 2009; 182: 2569-77.

120 Engel JB, Honig A, Schonhals T, Weidler C, Hausler S, Krockenberger $\mathrm{M}$, et al. Perifosine inhibits growth of human experimental endometrial cancers by blockade of AKT phosphorylation. Eur J Obstet Gynecol Reprod Biol 2008; 141: 64-9.

121 Floryk D, Thompson TC. Perifosine induces differentiation and cell death in prostate cancer cells. Cancer Lett 2008; 266: 216-26.

122 Hideshima T, Catley L, Yasui H, Ishitsuka K, Raje N, Mitsiades C, et al. Perifosine, an oral bioactive novel alkylphospholipid, inhibits Akt and induces in vitro and in vivo cytotoxicity in human multiple myeloma cells. Blood 2006; 107: 4053-62.

123 Patel V, Lahusen T, Sy T, Sausville EA, Gutkind JS, Senderowicz AM. Perifosine, a novel alkylphospholipid, induces p21 (WAF1) expression in squamous carcinoma cells through a p53-independent pathway, leading to loss in cyclin-dependent kinase activity and cell cycle arrest. Cancer Res 2002; 62: 1401-9.

124 Bailey HH, Mahoney MR, Ettinger DS, Maples WJ, Fracasso PM, Traynor AM, et al. Phase II study of daily oral perifosine in patients with advanced soft tissue sarcoma. Cancer 2006; 107: 2462-7.

125 Elrod HA, Lin YD, Yue P, Wang X, Lonial S, Khuri FR, et al. The alkylphospholipid perifosine induces apoptosis of human lung cancer cells requiring inhibition of Akt and activation of the extrinsic apoptotic pathway. Mol Cancer Ther 2007; 6: 2029-38.

126 Fei HR, Chen G, Wang JM, Wang FZ. Perifosine induces cell cycle arrest and apoptosis in human hepatocellular carcinoma cell lines by blockade of Akt phosphorylation. Cytotechnology 2010; 62: 449-60.

127 Vink SR, Schellens JH, Beijnen JH, Sindermann H, Engel J, Dubbelman $\mathrm{R}$, et al. Phase I and pharmacokinetic study of combined treatment with perifosine and radiation in patients with advanced solid tumours. Radiother Oncol 2006; 80: 207-13.

128 Ghobrial IM, Roccaro A, Hong F, Weller E, Rubin N, Leduc R, et al. Clinical and translational studies of a phase II trial of the novel oral Akt inhibitor perifosine in relapsed or relapsed/refractory Waldenstrom's macroglobulinemia. Clin Cancer Res 2010; 16: 1033-41.

129 Knowling M, Blackstein M, Tozer R, Bramwell V, Dancey J, Dore $\mathrm{N}$, et al. A phase II study of perifosine (D-21226) in patients with previously untreated metastatic or locally advanced soft tissue sarcoma: A National Cancer Institute of Canada Clinical Trials Group trial. Invest New Drugs 2006; 24: 435-9.

130 Bendell JC, Nemunaitis J, Vukelja SJ, Hagenstad C, Campos LT, Hermann RC, et al. Randomized placebo-controlled phase II trial of perifosine plus capecitabine as second- or third-line therapy in patients with metastatic colorectal cancer. J Clin Oncol 2011; 29: 4394-400.

131 Richardson PG, Wolf J, Jakubowiak A, Zonder J, Lonial S, Irwin D, et al. Perifosine plus bortezomib and dexamethasone in patients with relapsed/refractory multiple myeloma previously treated with bortezomib: results of a multicenter phase I/II trial. J Clin Oncol 2011; 29: 4243-9.

132 Pitter KL, Galban CJ, Galban S, Tehrani OS, Li F, Charles N, et al. Perifosine and $\mathrm{CCl} 779$ co-operate to induce cell death and decrease proliferation in PTEN-intact and PTEN-deficient PDGF-driven murine glioblastoma. PLoS One 2011; 6: e14545.

133 Sun H, Yu T, Li J. Co-administration of perifosine with paclitaxel synergistically induces apoptosis in ovarian cancer cells: more than just AKT inhibition. Cancer Lett 2011; 310: 118-28.

134 Berger MR, Tsoneva I, Konstantinov SM, Eibl H. Induction of apoptosis by erucylphospho-N,N,N-trimethylammonium is associated with changes in signal molecule expressionand location. Ann N Y Acad Sci 2003; 1010: 307-10.

135 Hideshima T, Catley L, Raje N, Chauhan D, Podar K, Mitsiades C, et al. Inhibition of Akt induces significant downregulation of survivin and cytotoxicity in human multiple myeloma cells. $\mathrm{Br} \mathrm{J}$ Haematol 2007; 138: 783-91.

136 Konstantinov SM, Eibl H, Berger MR. Alkylphosphocholines induce apoptosis in HL-60 and U-937 leukemic cells. Cancer Chemother Pharmacol 1998; 41: 210-6.

137 Nieto-Miguel T, Gajate C, Mollinedo F. Differential targets and subcellular localization of antitumor alkyl-lysophospholipid in leukemic versus solid tumor cells. J Biol Chem 2006; 281: 1483340.

138 Erdlenbruch B, Jendrossek V, Marx M, Hunold A, Eibl H, Lakomek M. Antitumor effects of erucylphosphocholine on brain tumor cells in vitro and in vivo. Anticancer Res 1998; 18: 2551-7.

139 Jendrossek V, Erdlenbruch B, Hunold A, Kugler W, Eibl H, Lakomek M. Erucylphosphocholine, a novel antineoplastic ether lipid, blocks growth and induces apoptosis in brain tumor cell lines in vitro. Int J Oncol 1999; 14: 15-22.

140 Veenman L, Alten J, Linnemannstons K, Shandalov Y, Zeno S, Lakomek M, et al. Potential involvement of FOF1-ATP(synth)ase and reactive oxygen species in apoptosis induction by the antineoplastic agent erucylphosphohomocholine in glioblastoma cell lines : a mechanism for induction of apoptosis via the $18 \mathrm{kDa}$ mitochondrial translocator protein. Apoptosis 2010; 15: 753-68.

141 Rudner J, Ruiner CE, Handrick R, Eibl HJ, Belka C, Jendrossek V. The Akt-inhibitor Erufosine induces apoptotic cell death in prostate cancer cells and increases the short term effects of ionizing radiation. Radiat Oncol 2010; 5: 108.

142 Fiegl M, Lindner LH, Juergens M, Eibl H, Hiddemann W, Braess J. Erufosine, a novel alkylphosphocholine, in acute myeloid leukemia: single activity and combination with other antileukemic drugs. Cancer Chemother Pharmacol 2008; 62: 321-9.

143 Martelli AM, Papa V, Tazzari PL, Ricci F, Evangelisti C, Chiarini F, et al. Erucylphosphohomocholine, the first intravenously applicable alkylphosphocholine, is cytotoxic to acute myelogenous leukemia cells through JNK- and PP2A-dependent mechanisms. Leukemia 2010; 24: 687-98. 
144 Yosifov DY, Todorov PT, Zaharieva MM, Georgiev KD, Pilicheva BA, Konstantinov SM, et al. Erucylphospho-N,N,N-trimethylpropylammonium (erufosine) is a potential antimyeloma drug devoid of myelotoxicity. Cancer Chemother Pharmacol 2011; 67: 13-25.

145 Konigs SK, Pallasch CP, Lindner LH, Schwamb J, Schulz A, Brinker $\mathrm{R}$, et al. Erufosine, a novel alkylphosphocholine, induces apoptosis in CLL through a caspase-dependent pathway. Leuk Res 2010; 34: 1064-9.

146 Zeng Z, Samudio IJ, Zhang W, Estrov Z, Pelicano H, Harris D, et al. Simultaneous inhibition of PDK1/AKT and Fms-like tyrosine kinase 3 signaling by a small-molecule KP372-1 induces mitochondrial dysfunction and apoptosis in acute myelogenous leukemia. Cancer Res 2006; 66: 3737-46.

147 Mandal M, Younes M, Swan EA, Jasser SA, Doan D, Yigitbasi O, et al. The Akt inhibitor KP372-1 inhibits proliferation and induces apoptosis and anoikis in squamous cell carcinoma of the head and neck. Oral Oncol 2006; 42: 430-9.

148 Koul D, Shen R, Bergh S, Sheng X, Shishodia S, Lafortune TA, et al. Inhibition of Akt survival pathway by a small-molecule inhibitor in human glioblastoma. Mol Cancer Ther 2006; 5: 637-44.

149 Mandal M, Kim S, Younes MN, Jasser SA, El-Naggar AK, Mills GB, et al. The Akt inhibitor KP372-1 suppresses Akt activity and cell proliferation and induces apoptosis in thyroid cancer cells. Br J Cancer 2005; 92: 1899-905.

150 Xi RG, Huang J, Li D, Wang XB, Wu L. Roles of PI3-K/Akt pathways in nanoparticle realgar powders-induced apoptosis in U937 cells. Acta Pharmacol Sin 2008; 29: 355-63.

151 Feun LG, Savaraj N, Bodey GP, Lu K, Yap BS, Ajani JA, et al. Phase I study of tricyclic nucleoside phosphate using a five-day continuous infusion schedule. Cancer Res 1984; 44: 3608-12.

152 Yang L, Dan HC, Sun M, Liu Q, Sun XM, Feldman Rl, et al. Akt/protein kinase $B$ signaling inhibitor-2, a selective small molecule inhibitor of Akt signaling with antitumor activity in cancer cells overexpressing Akt. Cancer Res 2004; 64: 4394-9.

153 Berndt N, Yang H, Trinczek B, Betzi S, Zhang Z, Wu B, et al. The Akt activation inhibitor TCN-P inhibits Akt phosphorylation by binding to the $\mathrm{PH}$ domain of Akt and blocking its recruitment to the plasma membrane. Cell Death Differ 2010; 17: 1795-804.

154 Powis G, Basseches PJ, Kroschel DM, Richardson RL, O'Connell MJ, Kvols LK. Disposition of tricyclic nucleoside-5'-monophosphate in blood and plasma of patients during phase I and II clinical trials. Cancer Treat Rep 1986; 70: 359-62.

155 Noh KH, Kang TH, Kim JH, Pai SI, Lin KY, Hung CF, et al. Activation of Akt as a mechanism for tumor immune evasion. Mol Ther 2009; 17: 439-47.

156 Schilcher RB, Haas CD, Samson MK, Young JD, Baker LH. Phase I evaluation and clinical pharmacology of tricyclic nucleoside 5'-phosphate using a weekly intravenous regimen. Cancer Res 1986; 46: 3147-51.

157 Feun LG, Blessing JA, Barrett RJ, Hanjani P. A phase II trial of tricyclic nucleoside phosphate in patients with advanced squamous cell carcinoma of the cervix. A Gynecologic Oncology Group Study. Am J Clin Oncol 1993; 16: 506-8.

158 Heerding DA, Rhodes N, Leber JD, Clark TJ, Keenan RM, Lafrance LV, et al. Identification of 4-(2-(4-amino-1,2,5-oxadiazol-3-yl)-1-ethyl7-\{[(3S)-3-piperidinylmethyl]oxy\}-1H-imidazo[4,5-c]pyridin-4-yl)-2methyl-3-butyn-2-ol (GSK690693), a novel inhibitor of AKT kinase. J Med Chem 2008; 51: 5663-79.

159 Rhodes N, Heerding DA, Duckett DR, Eberwein DJ, Knick VB, Lansing $\mathrm{TJ}$, et al. Characterization of an Akt kinase inhibitor with potent pharmacodynamic and antitumor activity. Cancer Res 2008; 68:
2366-74.

160 Levy DS, Kahana JA, Kumar R. AKT inhibitor, GSK690693, induces growth inhibition and apoptosis in acute lymphoblastic leukemia cell lines. Blood 2009; 113: 1723-9.

161 Altomare DA, Zhang L, Deng J, Di Cristofano A, Klein-Szanto AJ, Kumar R, et al. GSK690693 delays tumor onset and progression in genetically defined mouse models expressing activated Akt. Clin Cancer Res 2010; 16: 486-96.

162 Carol H, Morton CL, Gorlick R, Kolb EA, Keir ST, Reynolds CP, et al. Initial testing (stage 1) of the Akt inhibitor GSK690693 by the pediatric preclinical testing program. Pediatr Blood Cancer 2010; 55: 1329-37.

163 Hirai H, Sootome H, Nakatsuru Y, Miyama K, Taguchi S, Tsujioka K, et al. MK-2206, an allosteric Akt inhibitor, enhances antitumor efficacy by standard chemotherapeutic agents or molecular targeted drugs in vitro and in vivo. Mol Cancer Ther 2010; 9: 1956-67.

164 Liu R, Liu D, Trink E, Bojdani E, Ning G, Xing M. The Akt-specific inhibitor MK2206 selectively inhibits thyroid cancer cells harboring mutations that can activate the PI3K/Akt pathway. J Clin Endocrinol Metab 2011; 96: E577-85.

165 Knowles JA, Golden B, Yan L, Carroll WR, Helman EE, Rosenthal EL. Disruption of the AKT pathway inhibits metastasis in an orthotopic model of head and neck squamous cell carcinoma. Laryngoscope 2011; 121: 2359-65.

166 Meng J, Dai B, Fang B, Bekele BN, Bornmann WG, Sun D, et al. Combination treatment with MEK and AKT inhibitors is more effective than each drug alone in human non-small cell lung cancer in vitro and in vivo. PLoS One 2010; 5: e14124.

167 Balasis ME, Forinash KD, Chen YA, Fulp WJ, Coppola D, Hamilton $A D$, et al. Combination of farnesyltransferase and Akt inhibitors is synergistic in breast cancer cells and causes significant breast tumor regression in ErbB2 transgenic mice. Clin Cancer Res 2011; 17: 2852-62.

168 Cheng Y, Zhang Y, Zhang L, Ren X, Huber-Keener KJ, Liu X, et al. MK-2206, a novel allosteric inhibitor of Akt, synergizes with gefitinib against malignant glioma via modulating both autophagy and apoptosis. Mol Cancer Ther 2012; 11: 154-64.

169 Chen KF, Chen HL, Tai WT, Feng WC, Hsu CH, Chen PJ, et al. Activation of phosphatidylinositol 3-kinase/Akt signaling pathway mediates acquired resistance to sorafenib in hepatocellular carcinoma cells. J Pharmacol Exp Ther 2011; 337: 155-61.

170 Yap TA, Yan L, Patnaik A, Fearen I, Olmos D, Papadopoulos K, et al. First-in-man clinical trial of the oral pan-AKT inhibitor MK-2206 in patients with advanced solid tumors. J Clin Oncol 2011; 29:468895.

171 Liu Y, Jiang N, Wu J, Dai W, Rosenblum JS. Polo-like kinases inhibited by wortmannin. Labeling site and downstream effects. J Biol Chem 2007; 282: 2505-11.

172 Awasthi N, Yen PL, Schwarz MA, Schwarz RE. The efficacy of a novel, dual PI3K/mTOR inhibitor NVP-BEZ235 to enhance chemotherapy and antiangiogenic response in pancreatic cancer. J Cell Biochem 2012; 113: 784-91.

173 Roulin D, Waselle L, Dormond-Meuwly A, Dufour M, Demartines N, Dormond O. Targeting renal cell carcinoma with NVP-BEZ235, a dual $\mathrm{PI} 3 \mathrm{~K} / \mathrm{mTOR}$ inhibitor, in combination with sorafenib. Mol Cancer 2011; 10: 90.

174 Xu CX, Li Y, Yue P, Owonikoko TK, Ramalingam SS, Khuri FR, et al. The combination of RAD001 and NVP-BEZ235 exerts synergistic anticancer activity against non-small cell lung cancer in vitro and in vivo. PLoS One 2011; 6: e20899.

175 Zitzmann K, Ruden J, Brand S, Goke B, Lichtl J, Spottl G, et al. Com- 
pensatory activation of Akt in response to mTOR and Raf inhibitors a rationale for dual-targeted therapy approaches in neuroendocrine tumor disease. Cancer Lett 2010; 295: 100-9.

176 Leung E, Kim JE, Rewcastle GW, Finlay GJ, Baguley BC. Comparison of the effects of the PI3K/mTOR inhibitors NVP-BEZ235 and GSK2126458 on tamoxifen-resistant breast cancer cells. Cancer Biol Ther 2011; 11: 938-46.
177 Dubrovska A, Elliott J, Salamone RJ, Kim S, Aimone LJ, Walker JR, et al. Combination therapy targeting both tumor-initiating and differentiated cell populations in prostate carcinoma. Clin Cancer Res 2010; 16: 5692-702.

178 Robinson JP, Vanbrocklin MW, Lastwika KJ, McKinney AJ, Brandner $\mathrm{S}$, Holmen SL. Activated MEK cooperates with Ink4a/Arf loss or Akt activation to induce gliomas in vivo. Oncogene 2011; 30: 1341-50. 